Atmos. Chem. Phys., 17, 11041-11063, 2017

https://doi.org/10.5194/acp-17-11041-2017

(C) Author(s) 2017. This work is distributed under

the Creative Commons Attribution 3.0 License.

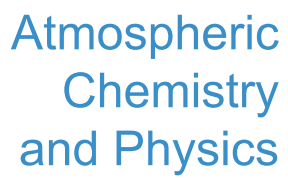

(c) (P)

\title{
Pre-monsoon air quality over Lumbini, a world heritage site along the Himalayan foothills
}

\author{
Dipesh Rupakheti ${ }^{1,2}$, Bhupesh Adhikary ${ }^{3}$, Puppala Siva Praveen ${ }^{3}$, Maheswar Rupakheti ${ }^{4,5}$, Shichang Kang ${ }^{2,6,7}$, \\ Khadak Singh Mahata ${ }^{4}$, Manish Naja ${ }^{8}$, Qianggong Zhang ${ }^{1,7}$, Arnico Kumar Panday ${ }^{3}$, and Mark G. Lawrence ${ }^{4}$ \\ ${ }^{1}$ Key Laboratory of Tibetan Environment Changes and Land Surface Processes, Institute of Tibetan Plateau Research, \\ Chinese Academy of Sciences, Beijing 100101, China \\ ${ }^{2}$ University of Chinese Academy of Sciences, Beijing 100049, China \\ ${ }^{3}$ International Centre for Integrated Mountain Development (ICIMOD), Kathmandu, Nepal \\ ${ }^{4}$ Institute for Advanced Sustainability Studies (IASS), Potsdam 14467, Germany \\ ${ }^{5}$ Himalayan Sustainability Institute (HIMSI), Kathmandu, Nepal \\ ${ }^{6}$ State Key Laboratory of Cryospheric Science, Cold and Arid Regions Environmental and Engineering Research Institute \\ (CAREERI), Lanzhou 730000, China \\ ${ }^{7}$ Center for Excellence in Tibetan Plateau Earth Sciences, Chinese Academy of Sciences, Beijing 100085, China \\ ${ }^{8}$ Aryabhatta Research Institute of Observational Sciences (ARIES), Nainital, India
}

Correspondence to: Dipesh Rupakheti (dipesh.rupakheti@itpcas.ac.cn) and Shichang Kang (shichang.kang@1zb.ac.cn)

Received: 19 May 2016 - Discussion started: 17 June 2016

Revised: 4 August 2017 - Accepted: 11 August 2017 - Published: 18 September 2017

\begin{abstract}
Lumbini, in southern Nepal, is a UNESCO world heritage site of universal value as the birthplace of Buddha. Poor air quality in Lumbini and surrounding regions is a great concern for public health as well as for preservation, protection and promotion of Buddhist heritage and culture. We present here results from measurements of ambient concentrations of key air pollutants (PM, BC, $\left.\mathrm{CO}, \mathrm{O}_{3}\right)$ in Lumbini, first of its kind for Lumbini, conducted during an intensive measurement period of 3 months (April-June 2013) in the pre-monsoon season. The measurements were carried out as a part of the international air pollution measurement campaign; SusKat-ABC (Sustainable Atmosphere for the Kathmandu Valley - Atmospheric Brown Clouds). The main objective of this work is to understand and document the level of air pollution, diurnal characteristics and influence of open burning on air quality in Lumbini. The hourly average concentrations during the entire measurement campaign ranged as follows: $\mathrm{BC}$ was $0.3-30.0 \mu \mathrm{g} \mathrm{m}^{-3}, \mathrm{PM}_{1}$ was 3.6-

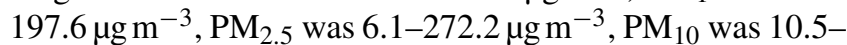
$604.0 \mu \mathrm{g} \mathrm{m}^{-3}, \mathrm{O}_{3}$ was $1.0-118.1 \mathrm{ppbv}$ and $\mathrm{CO}$ was 125.0 $1430.0 \mathrm{ppbv}$. These levels are comparable to other very heavily polluted sites in South Asia. Higher fraction of coarsemode PM was found as compared to other nearby sites in
\end{abstract}

the Indo-Gangetic Plain region. The $\triangle \mathrm{BC} / \triangle \mathrm{CO}$ ratio obtained in Lumbini indicated considerable contributions of emissions from both residential and transportation sectors. The $24 \mathrm{~h}$ average $\mathrm{PM}_{2.5}$ and $\mathrm{PM}_{10}$ concentrations exceeded the WHO guideline very frequently (94 and $85 \%$ of the sampled period, respectively), which implies significant health risks for the residents and visitors in the region. These air pollutants exhibited clear diurnal cycles with high values in the morning and evening. During the study period, the worst air pollution episodes were mainly due to agro-residue burning and regional forest fires combined with meteorological conditions conducive of pollution transport to Lumbini. Fossil fuel combustion also contributed significantly, accounting for more than half of the ambient BC concentration according to aerosol spectral light absorption coefficients obtained in Lumbini. WRF-STEM, a regional chemical transport model, was used to simulate the meteorology and the concentrations of pollutants to understand the pollutant transport pathways. The model estimated values were $\sim 1.5$ to 5 times lower than the observed concentrations for $\mathrm{CO}$ and $\mathrm{PM}_{10}$, respectively. Model-simulated regionally tagged $\mathrm{CO}$ tracers showed that the majority of $\mathrm{CO}$ came from the upwind region of Ganges Valley. Model performance needs significant improvement 
in simulating aerosols in the region. Given the high air pollution level, there is a clear and urgent need for setting up a network of long-term air quality monitoring stations in the greater Lumbini region.

\section{Introduction}

The Indo-Gangetic Plain (IGP) stretches over $2000 \mathrm{~km}$ encompassing a vast area of land in northern South Asia: the eastern parts of Pakistan, most of northern and eastern India, southern part of Nepal and almost all of Bangladesh. The Himalayan mountains and their foothills stretch along the northern edge of IGP. The IGP region is among the most fertile and most intensely farmed region of the world. It is a heavily populated region with about 900 million residents or $12 \%$ of the world's population. Four megacities - Lahore, Delhi, Kolkata and Dhaka - are located in the IGP region, with dozens more cities with populations exceeding 1 million. The region has witnessed impressive economic growth in recent decades but unfortunately it has also become one of the most polluted, and an air pollution "hotspot" of local, regional and global concern (Ramanathan et al., 2007). Main factors contributing to air pollution in the IGP and surrounding regions include emissions from vehicles, thermal power plants, industries, biomass and fossil fuel used in cooking and heating activities, agricultural activities, crop residue burning and forest fires. Air pollution gets transported long distances away from emission sources and across national borders. As a result, the IGP and adjacent regions get shrouded with a dramatic annual buildup of regional-scale plumes of air pollutants, known as atmospheric brown clouds $(\mathrm{ABC})$, during the long and dry winter and pre-monsoon seasons each year (Ramanathan and Carmichael, 2008). Figure 1 shows monthly synoptic wind and mean aerosol optical depth during April-June 2013 over South Asia. Very high aerosol optical depth along the entire stretch of IGP reflects the severity of air pollution over large areas in the region.

Poor air quality continues to pose a significant threat to human health in the region. In a new study of global burden of disease released recently, Forouzanfar et al. (2015) estimated that in 2013 around 1.7 million people died prematurely in Pakistan, India, Nepal and Bangladesh as a result of air pollution exposure, nearly $30 \%$ of global total premature deaths due to air pollution. Air pollution also affects precipitation (e.g., South Asian monsoon), agricultural productivity, ecosystems, tourism, climate and broadly socioeconomic and national development goals of the countries in the region (Burney and Ramanathan, 2014; Shindell et al., 2012; Ramanathan and Carmichael, 2008). It has also been linked to intensification of cold wave and winter fog in the IGP region over recent decades (Lawrence and Lelieveld, 2010, and references therein; Safai et al., 2009; Ganguly et al., 2006). Besides high levels of aerosol loading as shown in
Fig. 1, IGP also has very high levels of ground-level ozone or tropospheric ozone $\left(\mathrm{O}_{3}\right)$ (e.g., Ramanathan and Carmichael, 2008), which is toxic to plant and human health and a major greenhouse gas (IPCC, 2013; Shindell et al., 2012; Mohnen et al., 1993). South Asia, in particular IGP, has been projected to be the most ozone-polluted region in the world by 2030 (Stevenson et al., 2006). The majority of crop loss in different parts of the world results from effects of ozone on crop health and productivity (Shindell et al., 2012). Burney and Ramanathan (2014) also reported a significant loss in wheat and rice yields in India from 1980 to 2010 due to direct effects of black carbon (BC) and $\mathrm{O}_{3}$. $\mathrm{BC}$ and $\mathrm{O}_{3}$ are two key short-lived climate pollutants. Similarly, species like fine particles and carbon monoxide (CO) are potent to health damages by posing impacts upon the respiratory and cardiovascular system and even also to the climate system (Singh et al., 2017, and references therein). Because of the IGP's close proximity to the Himalaya-Tibetan plateau region, this once relatively clean region is now subjected to increasing air pollution transported from regions such as the IGP, which can exert additional risks to sensitive ecosystems in the mountain region (e.g., Lüthi et al., 2015; Marinoni et al., 2013; Duchi et al., 2011). However, air pollution transport pathways to Himalayas are still not yet fully understood.

Monuments and buildings made with stones are vulnerable to air pollution damage (Brimblecombe, 2003; Gauri and Holdren, 1981). The damage to the monuments and buildings could be in various forms like corrosion, soiling, abrasion and discoloration. For example, a recent study has reported that deposition of light absorbing aerosol particles (black carbon, brown carbon) and dust is responsible for the discoloration of Taj Mahal, a world-famous monument in India (Bergin et al., 2015). Lumbini, located near the northern edge of the central IGP, is famous as the birthplace of the Lord Buddha and thus a UNESCO world heritage site of outstanding universal value to humanity. Since the study area is renowned for its historical and archaeological significance, Lumbini is also getting worldwide attention for poor air quality in the region. There was no regular air quality monitoring in Lumbini at the time of our measurement campaign.

Through this study, we want to understand the level of air pollution, its diurnal characteristic and the influence of open burning on air quality in Lumbini. We carried out continuous measurements of ambient concentrations of key air pollutants (PM, BC, $\mathrm{CO}, \mathrm{O}_{3}$ ) and meteorological parameters during an intensive measurement period of 3 months (AprilJune) in the year 2013. These are the first reported pollutant measurements for Lumbini. A regional chemical transport model called Sulfur Transport and dEposition Model (STEM) was used to simulate the variations of meteorological parameters and air pollutants during the observation period to examine the extent to which a state-of-the-art, widely used air quality model is able to simulate the observations, as an indication for where there are still gaps in our knowledge and what further measurements and emissions dataset de- 

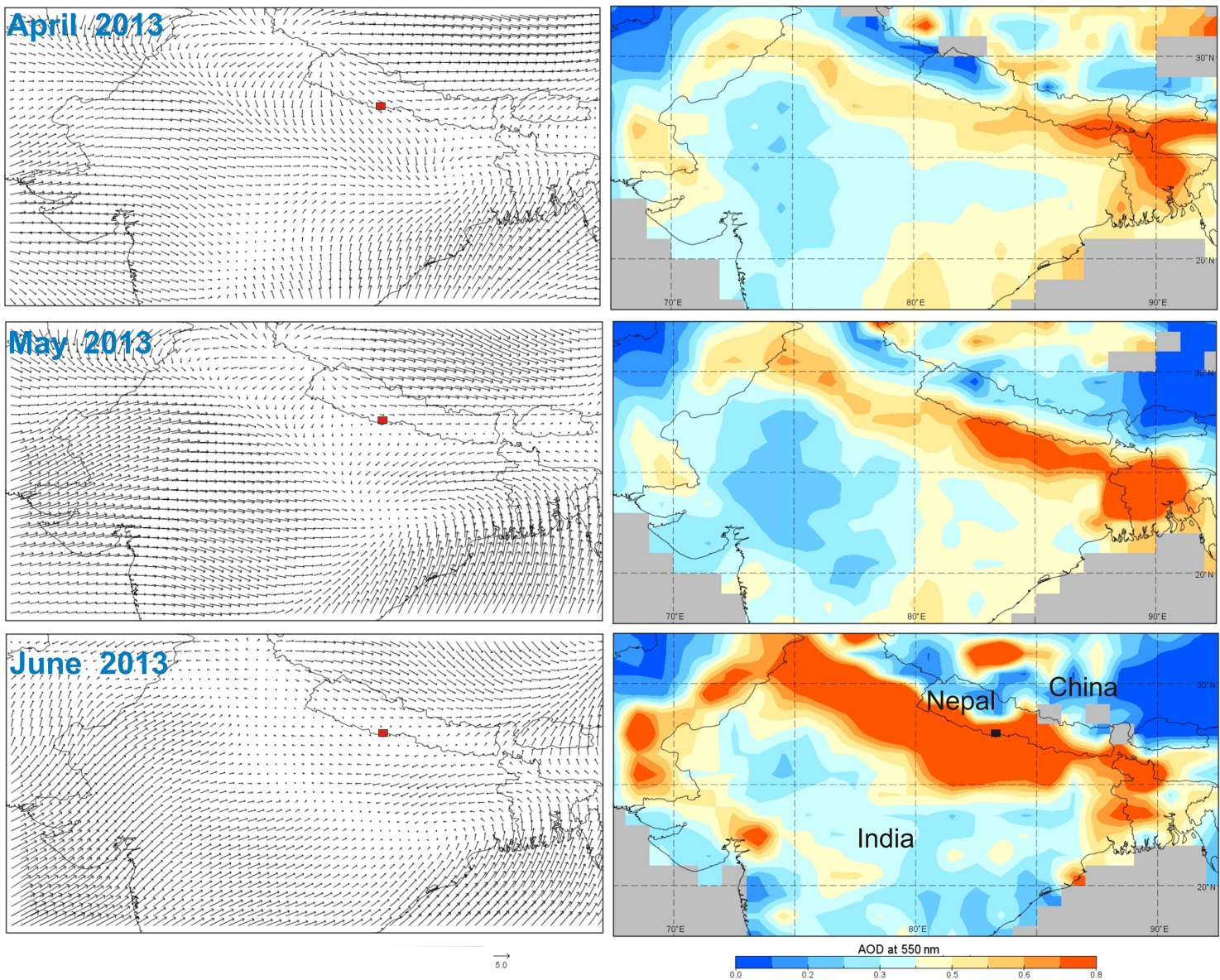

Figure 1. Monthly synoptic wind (at $1000 \mathrm{hPa}$ ) for April, May and June 2013, based on NCEP/NCAR reanalysis data where the orientations of arrows refer to wind direction and the length of arrows represents the magnitude of wind ( $\mathrm{ms}^{-1}$ ). Red square box in the figure (left) represents the location of Lumbini. Figures on the right side represent monthly aerosol optical depth acquired with the MODIS instrument aboard TERRA satellite. High aerosol loading can be seen over the entire Indo-Gangetic Plain (IGP). Light gray color used in the figure represents the absence of data.

velopments are needed. Model-simulated regionally tagged $\mathrm{CO}$ tracers were used to identify emission source regions impacting pollutant concentration observed at Lumbini. Satellite data have also been used to understand the high-pollution events during the monitoring period. These measurements were carried out as a part of the SusKat-ABC international air pollution measurement campaign (Rupakheti et al., 2017) jointly led by the International Centre for Integrated Mountain Development (ICIMOD), Kathmandu, Nepal, and Institute for Advanced Sustainability Studies (IASS), Potsdam, Germany.

\section{Experimental setup}

\subsection{Sampling site}

The Lumbini measurement site $\left(27^{\circ} 29.387^{\prime} \mathrm{N}, 83^{\circ} 16.745^{\prime} \mathrm{E}\right.$; elevation: $\sim 100$ ma.s.l.) is located at the premise of the
Lumbini International Research Institute (LIRI), a Buddhist library in Lumbini in the Rupandehi district. According to the national census conducted in 2011, the total population of Rupandehi district is about 900000 with a population density of about 650 people $\mathrm{km}^{-2}$, which is the fourth most densely populated district in the country. Over 130000 tourists visited Lumbini in 2014 (http://www.tourism.gov.np/ne/). A local road (asphalt) lies about $200 \mathrm{~m}$ north of the sampling site and experiences intermittent passing of vehicles. About $25 \mathrm{~km}$ north of Lumbini the foothills begin, while the main peaks of the Himalayas are $140 \mathrm{~km}$ to the north. The remaining three sides are surrounded by flat plain land of Nepal and India. The site is only about $8 \mathrm{~km}$ from the Nepal-India border in the south. A three-storied $10 \mathrm{~m}$ tall water tower was used as the platform for the automatic weather station (AWS), while remaining instruments were placed inside a room near the base of the tower. An uninterrupted power back up was set up in order to assure the regular power sup- 
ply even during hours with scheduled power cuts during the monitoring period. Figure S1 in the Supplement shows the location of Lumbini, the Kenzo Tange Master Plan area of the Lumbini development project, the sampling tower and a brief discussion on the surroundings of the site. Outside of the Master Plan area lies a vast area of agricultural fields, village pockets, several brick kilns and cement industries.

\subsection{Monitoring instruments}

The summary of instruments deployed in Lumbini is presented in Table 1. All data were collected in Nepal standard time (NST), which is GMT + 05:45 h. $\mathrm{PM}_{1}, \mathrm{PM}_{2.5}$ and $\mathrm{PM}_{10}$ mass concentrations were monitored continuously with the EDM 164 (Grimm Aerosol Technik, Germany), which uses the light scattering at $655 \mathrm{~nm}$ to derive mass concentrations. Similarly, aerosol light absorptions at seven wavelengths $(370,470,520,590,660,880,950 \mathrm{~nm})$ were measured continuously with an Aethalometer (model AE-42, Magee Scientific, USA), averaging and reporting data every $5 \mathrm{~min}$. It was operated at a flow rate of $5 \mathrm{Lmin}^{-1}$. No cutoff was applied for inlet; hence the reported concentration of $\mathrm{BC}$ is total suspended BC particles. As described by the manufacturer, ambient $\mathrm{BC}$ concentration is derived from light absorption at $880 \mathrm{~nm}$ using a specific mass absorption cross section. To obtain BC concentration in Lumbini, we used a specific mass absorption cross-section value of $8 \mathrm{~m}^{2} \mathrm{~g}^{-1}$ for the $880 \mathrm{~nm}$ channel. A similar value has been previously used for BC measurement in the IGP (Praveen et al., 2012). To remove the filter loading effect, we used the correction method suggested by Schmid et al. (2006), which was also used by Praveen et al. (2012) for BC measurements at a rural site in the IGP. Surface $\mathrm{O}_{3}$ concentration was measured continuously with an ozone analyzer (model $49 i$, Thermo Scientific, USA) which utilizes UV ( $254 \mathrm{~nm}$ wavelength) photometric technology to measure ozone concentration in ambient air. A CO analyzer (model $48 i$, Thermo Scientific, USA) was used to monitor ambient $\mathrm{CO}$ concentration. The ambient air was drawn through a $6 \mu \mathrm{m}$ pore-size Savillex $47 \mathrm{~mm}$ filter at the inlet that removed the particles before sending the air into the $\mathrm{CO}$ and $\mathrm{O}_{3}$ analyzers using a Teflon tube. The filters were replaced every 7-10 days depending on particle loading, based on manual inspection. The $\mathrm{CO}$ instrument was set to auto-zero at a regular interval of $6 \mathrm{~h}$. Local meteorological parameters (temperature, relative humidity $(\mathrm{RH})$, wind speed (WS), wind direction (WD), precipitation and global solar radiation) were monitored with an AWS (Campbell Scientific, Loughborough, UK), recording data every minute.

\subsection{Regional chemical transport model}

Aerosol and trace gas distributions were simulated using a regional chemical transport model. STEM, a 3-D Eulerian model that has been used extensively in the past to characterize air pollutants in South Asian region (Adhikary et al., 2010, 2007), was used to understand observations at Lumbini. The Weather Research and Forecasting (WRF) model (Skamarock et al., 2008) version 3.5.1 was used to generate the required meteorological variables necessary for simulating pollutant transport in STEM. The model domain was centered at $24.94^{\circ} \mathrm{N}$ latitude and $82.55^{\circ} \mathrm{E}$ longitude, covering a region from 3.390 to $43.308^{\circ} \mathrm{N}$ latitude and 34.880 to $130.223^{\circ} \mathrm{E}$ longitude. The model has $425 \times 200$ horizontal grid cells with grid resolution of $25 \mathrm{~km} \times 25 \mathrm{~km}$ and 41 vertical layers with the top of the model set at 50 mbar. The WRF model was run from 1 November 2012 to 30 June 2013. However, for this study, modeled data from April to June 2013 only have been used. The WRF model was initialized with FNL data available from NCAR/UCAR site (http://rda.ucar.edu/datasets/ds083.2/).

The tracer version of STEM provides mass concentration of sulfate, BC (hydrophilic and hydrophobic), organic carbon (OC), sea salt (fine and coarse mode), dust (fine $\mathrm{PM}_{2.5}$ and $\mathrm{PM}_{10}$ ), $\mathrm{CO}$ (open burning and anthropogenic) and regionally tagged $\mathrm{CO}$ tracers. STEM domain size, resolution and projection are those of the WRF model. Details about the tracer version of STEM are outlined elsewhere (Kulkarni et al., 2015; Adhikary et al., 2007). Anthropogenic emission of various pollutants $\left(\mathrm{CH}_{4}, \mathrm{CO}, \mathrm{SO}_{2}, \mathrm{NO}_{x}\right.$, NMVOC, $\mathrm{NH}_{3}, \mathrm{PM}_{10}, \mathrm{PM}_{2.5}$, BC and OC) used in this analysis were taken from EDGAR HTAP v2 (http://edgar.jrc.ec. europa.eu/htap_v2/index.php?SECURE=123) for 2010. Annual emissions given in $\mathrm{kg} \mathrm{m}^{-2} \mathrm{sec}^{-1}$ at $0.1^{\circ} \times 0.1^{\circ}$ resolution were converted to molecules $\mathrm{cm}^{-2} \mathrm{sec}^{-1}$ and re-gridded to $25 \mathrm{~km} \times 25 \mathrm{~km}$ resolution using four-point interpolation techniques available in the STEM emission preprocessor. The emissions were given a diurnal profile using previously used parameterization available in the preprocessor. Open biomass burning emissions on a daily basis during the simulated period were taken from data obtained from the FINN model (Wiedinmyer et al., 2011). As with the WRF model, STEM was run from 2 November 2012 to 30 June 2013 but data presented here are only during the intensive field campaign period.

\section{Results and discussions}

\subsection{Meteorology}

Hourly average time series of various meteorological parameters like precipitation in $\mathrm{mm} \mathrm{h}^{-1}$ (Prec), temperature in ${ }^{\circ} \mathrm{C}(T)$, relative humidity in $\%$, WS in $\mathrm{m} \mathrm{s}^{-1}$ and WD in degree during the monitoring period are shown in Fig. 2. Meteorological parameters were obtained with the sensors at the height of $\sim 12 \mathrm{~m}$ from the ground. Meteorology results from WRF model simulations have been used to indicate any significantly different air-mass type present during the measurement campaign after the meteorological observations malfunctioned. Precipitation data were derived from 
Table 1. Summary of instruments deployed during monitoring in Lumbini.

\begin{tabular}{|c|c|c|c|c|c|}
\hline $\begin{array}{l}\text { Instrument } \\
\text { (model) }\end{array}$ & Manufacturer & Parameters & $\begin{array}{l}\text { Inlet/sensor height } \\
\text { (above ground) }\end{array}$ & $\begin{array}{l}\text { Sampling } \\
\text { interval }\end{array}$ & $\begin{array}{l}\text { Sampled } \\
\text { period }\end{array}$ \\
\hline $\begin{array}{l}\text { Environmental } \\
\text { dust monitor } \\
\text { (EDM 164) }\end{array}$ & $\begin{array}{l}\text { Grimm } \\
\text { Aerosol } \\
\text { Technik, } \\
\text { Germany }\end{array}$ & $\mathrm{PM}_{1}, \mathrm{PM}_{2.5}, \mathrm{PM}_{10}$ & $5 \mathrm{~m}$ & $5 \mathrm{~min}$ & $\begin{array}{l}2 \text { Apr-10 May, } \\
2-13 \text { Jun }\end{array}$ \\
\hline $\begin{array}{l}\text { Aethalometer } \\
\text { (AE42) }\end{array}$ & $\begin{array}{l}\text { Magee Sci- } \\
\text { entific, USA }\end{array}$ & $\begin{array}{l}\text { Aerosol light } \\
\text { absorption at seven } \\
\text { wavelengths and } \\
\text { BC concentration }\end{array}$ & $3 \mathrm{~m}$ & $5 \mathrm{~min}$ & 1 Apr-5 Jun \\
\hline $\begin{array}{l}\mathrm{CO} \text { analyzer } \\
(48 i)\end{array}$ & $\begin{array}{l}\text { Thermo Sci- } \\
\text { entific, USA }\end{array}$ & $\mathrm{CO}$ concentration & $3 \mathrm{~m}$ & $1 \mathrm{~min}$ & 1 Apr-15 Jun \\
\hline $\begin{array}{l}\mathrm{O}_{3} \text { analyzer } \\
(49 i)\end{array}$ & $\begin{array}{l}\text { Thermo Sci- } \\
\text { entific, USA }\end{array}$ & $\mathrm{O}_{3}$ concentration & $3 \mathrm{~m}$ & $1 \mathrm{~min}$ & 1 Apr-15 Jun \\
\hline $\begin{array}{l}\text { Automatic } \\
\text { weather station } \\
\text { (AWS) }\end{array}$ & $\begin{array}{l}\text { Campbell } \\
\text { Scientific, } \\
\text { UK }\end{array}$ & $\begin{array}{l}T, \mathrm{RH}, \mathrm{WS}, \mathrm{WD}, \\
\text { global radiation, } \\
\text { precipitation }\end{array}$ & $12 \mathrm{~m}$ & $1 \mathrm{~min}$ & 1 Apr-15 Jun \\
\hline
\end{tabular}

TRMM satellite (TRMM_3B42_007 at a horizontal resolution of $0.25^{\circ}$ ) from the Giovanni platform (http://giovanni. gsfc.nasa.gov/giovanni/) as the rain gauge malfunctioned during the sampling period. Precipitation data from TRMM (Fig. 2) show that Lumbini was relatively dry in the early portion of the measurement campaign, while the site did experience some rainfall events as the pre-monsoon edged closer to the monsoon onset. This lowered aerosol loading in the later half of the measurement campaign due to washout and less biomass open burning. Comparison of WRF model outputs with TRMM data shows that the model underpredicts rainfall through out the campaign.

Average observed temperature for the sampling period until the sensor stopped working (on 8 May 2013, i.e., for 38 days of measurement) was $28.1^{\circ} \mathrm{C}$ (minimum: $16.5^{\circ} \mathrm{C}$, maximum: $40^{\circ} \mathrm{C}$ ). Average temperature from the model, during same period, was $31^{\circ} \mathrm{C}$, with values ranging between 19 and $40^{\circ} \mathrm{C}$. As shown in Fig. 2, the model captures the variability of temperature and is mostly within the range of daily values. However, the model has a high bias and does not capture well daily minimum temperature values. The model data were interpolated to match the observation site's latitude, longitude and altitude for all variables discussed in this paper. In addition, the model does not show any large variation in temperature for the campaign period after the sensors stopped working. This insight will be useful to interpret pollution data later on. For the same period (until the sensor stopped working), the average (observed) $\mathrm{RH}$ was $\sim 50 \%$ (ranging from 10.5 to $97.5 \%$ ) whereas the model showed the average RH to be $\sim 23 \%$ with values ranging between 6 and $78 \%$. RH values are highly underestimated by the model but, as previously mentioned, the model does not show significant changes in RH during the measurement campaign after the observations stopped working.
Average observed wind speed during the study period was $2.4 \mathrm{~m} \mathrm{~s}^{-1}$, with hourly values ranging between 0.03 and $7.4 \mathrm{~m} \mathrm{~s}^{-1}$, whereas from the WRF model average wind speed was found to be $3.2 \mathrm{~m} \mathrm{~s}^{-1}$ (range: $0.06-11.1 \mathrm{~m} \mathrm{~s}^{-1}$ ). Diurnal variation of observed hourly average wind speed suggested that wind speeds were lower during nights and mornings while higher wind speed prevailed during daytime, with average winds $>3 \mathrm{~ms}^{-1}$ up to $\sim 3.3 \mathrm{~m} \mathrm{~s}^{-1}$ between 09:00 and 13:00 LT (Supplement, Fig. S2, lower panel). Highspeed strong winds $\left(>4 \mathrm{~m} \mathrm{~s}^{-1}\right)$ were from the NW direction during the month of April and later switched to the almost opposite direction, i.e., SE direction, from the month of May onwards. The monthly wind rose plot using the data from both observation and modeling, where the difference in the pattern could be potentially due to the data resolution, is shown in Fig. S3. Comparing modeled wind direction prediction skills at the surface with one point measurement is not sufficient. However, in the absence of other measurements, we also show the comparison of wind direction as an indication of model performance over this region and not as model validation where a more high-resolution modeling and sensitivity analysis of model physics and chemistry may be required. Discrepancy on model results might have occurred due to various factors inherently uncertain in a weather prediction using a model. Additionally, air pollution transport occurs via elevated layers and is not limited to surface winds. We show NCEP/NCAR reanalysis plots at $850 \mathrm{hPa}$ in Fig. S3 to illustrate the distinctly differing wind direction compared to the surface winds seen from observations as well as NCEP/NCAR reanalysis plot at $1000 \mathrm{hPa}$ shown in Fig. 1. There are no upper wind measurement data nearby Lumbini to show model performance. Regardless, we believe that air quality model data are vital for understand- 


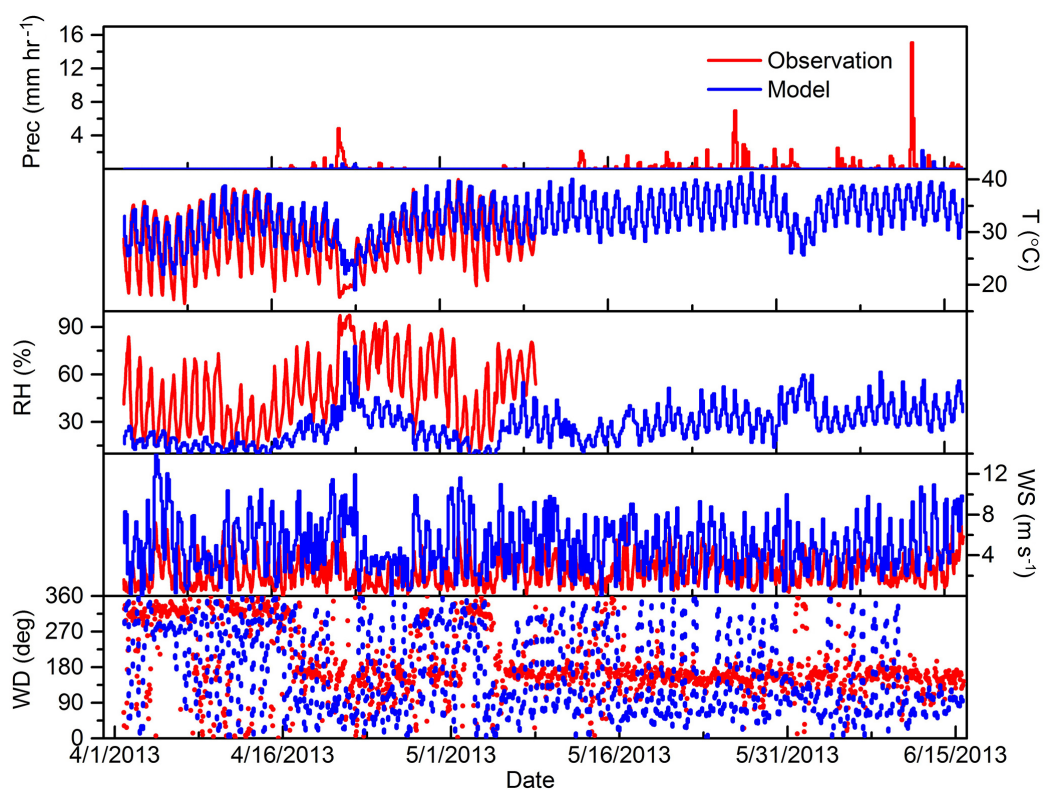

Figure 2. Time series of hourly average observed (red) and model estimated (blue) meteorological parameters at Lumbini, Nepal, for the entire sampling period from 1 April to 15 June 2013.

ing pollutant transport in an area where observation data are non-existent or incomplete.

\subsection{Air quality}

\subsubsection{General overview, PM ratios and influence of meteorology on pollution concentrations}

Figure 3 shows hourly averaged time series of observed $\mathrm{BC}, \mathrm{PM}_{1}, \mathrm{PM}_{2.5}, \mathrm{PM}_{10}, \mathrm{O}_{3}$ and $\mathrm{CO}$ observed at Lumbini during the study period. Similar temporal behavior was shown by $\mathrm{BC}$, particulate matter fractions $\left(\mathrm{PM}_{1}, \mathrm{PM}_{2.5}\right.$ and $\mathrm{PM}_{10}$ ) and $\mathrm{CO}$. The gap in the figure (for PM time series) is due to the power interruption to the instrument. BC concentrations during the measurement period ranged between 0.3 and $29.9 \mu \mathrm{g} \mathrm{m}^{-3}$ with a mean $( \pm \mathrm{SD})$ value of 4.9 $( \pm 3.8) \mu \mathrm{g} \mathrm{m}^{-3}$. BC concentrations in Lumbini during premonsoon months are lower compared to $\mathrm{BC}$ concentrations observed in the Kathmandu Valley because of high number of vehicles plying on the street, brick kilns and other industries in Kathmandu Valley (Sharma et al., 2012; Putero et al., 2015). The lowest concentration was observed during a rainy day (21-22 April) whereas the highest concentration was observed during a period of forest fire (detailed in Sect. 3.3). For the entire measurement period, we found average (of hourly average values) $\mathrm{PM}_{1}$ of $35.8 \pm 25.6 \mu \mathrm{g} \mathrm{m}^{-3}$ (minimum-maximum range: $3.6-197.6 \mu \mathrm{g} \mathrm{m}^{-3}$ ), $\mathrm{PM}_{2.5}$ of $53.1 \pm 35.1 \mu \mathrm{g} \mathrm{m}^{-3}\left(6.1-272.2 \mu \mathrm{g} \mathrm{m}^{-3}\right), \mathrm{PM}_{10}$ of $128.9 \pm$ $91.9 \mu \mathrm{g} \mathrm{m}^{-3}\left(10.5-603.9 \mu \mathrm{g} \mathrm{m}^{-3}\right)$ and coarse-mode fraction of $75.7 \pm 61.7 \mu \mathrm{g} \mathrm{m}^{-3}\left(1.9-331.8 \mu \mathrm{g} \mathrm{m}^{-3}\right)$. The coarse-mode $\left(\mathrm{PM}_{10-2.5}\right)$ fraction was $\sim 60 \%$ of the $\mathrm{PM}_{10}$. The share of coarse-mode aerosol to $\mathrm{PM}_{10}$ in Lumbini was higher than that observed in other sites in the IGP, such as Guwahiti, India (42\%) (Tiwari et al., 2017), and Dibrugarh, India (9$16 \%$ ) (Pathak et al., 2013), both in eastern IGP and Delhi (38\%) (Tiwari et al., 2015) in western IGP, indicating the higher contribution of coarse aerosols in Lumbini, likely lifted from soils from nearby agricultural fields and construction materials by stronger winds during pre-monsoon season. Values of coarse-mode fraction, similar to Lumbini, have been reported by Misra et al. (2014) at Kanpur for dust dominated and mixed aerosols events.

The share of BC in PM fractions was found to be $\sim 13 \%$ in $\mathrm{PM}_{1}, 9 \%$ in $\mathrm{PM}_{2.5}$ and $\sim 4 \%$ in $\mathrm{PM}_{10}$ but the correlation coefficients of $\mathrm{BC}$ with three $\mathrm{PM}$ fractions were found to be $0.89\left(\mathrm{PM}_{1}\right), 0.88\left(\mathrm{PM}_{2.5}\right)$ and $0.69\left(\mathrm{PM}_{10}\right)$, indicating the commonality in the sources of these pollutants. The contribution of $\mathrm{BC}$ in $\mathrm{PM}_{1}$ was found to be $\sim 12 \%$ in Kanpur during February-March (Kumar et al., 2016a), similar to Lumbini. Regarding the share of $\mathrm{BC}$ in $\mathrm{PM}_{10}$, the share observed in Lumbini $(\sim 4 \%)$ was similar to that observed over Varanasi ( $\sim 340 \mathrm{~km}$ south of our site) in central IGP $(5 \%)$ ) (Tiwari et al., 2016) and Dibrugarh in eastern IGP $(\sim 5 \%)$ (Pathak et al., 2013). Thus our results indicate that despite our station being located at the northern edge of the IGP along the foothills of the Himalayan range, the share of $\mathrm{BC}$ in $\mathrm{PM}$ is similar to that found in heavily polluted sites in the central and eastern IGP.

In Lumbini, the average (hourly) share of $\mathrm{PM}_{1}$ in $\mathrm{PM}_{2.5}$, $\mathrm{PM}_{1}$ in $\mathrm{PM}_{10}$ and $\mathrm{PM}_{2.5}$ in $\mathrm{PM}_{10}$ was found to be $\sim 70$, 34 and $47 \%$, respectively. Regarding other sites in IGP region, $\mathrm{PM}_{2.5} / \mathrm{PM}_{10}$ ratios were reported to be $56 \%$ in Kanpur (Snider et al., 2016), $60 \%$ in Varanasi (Kumar et al., 2015), 

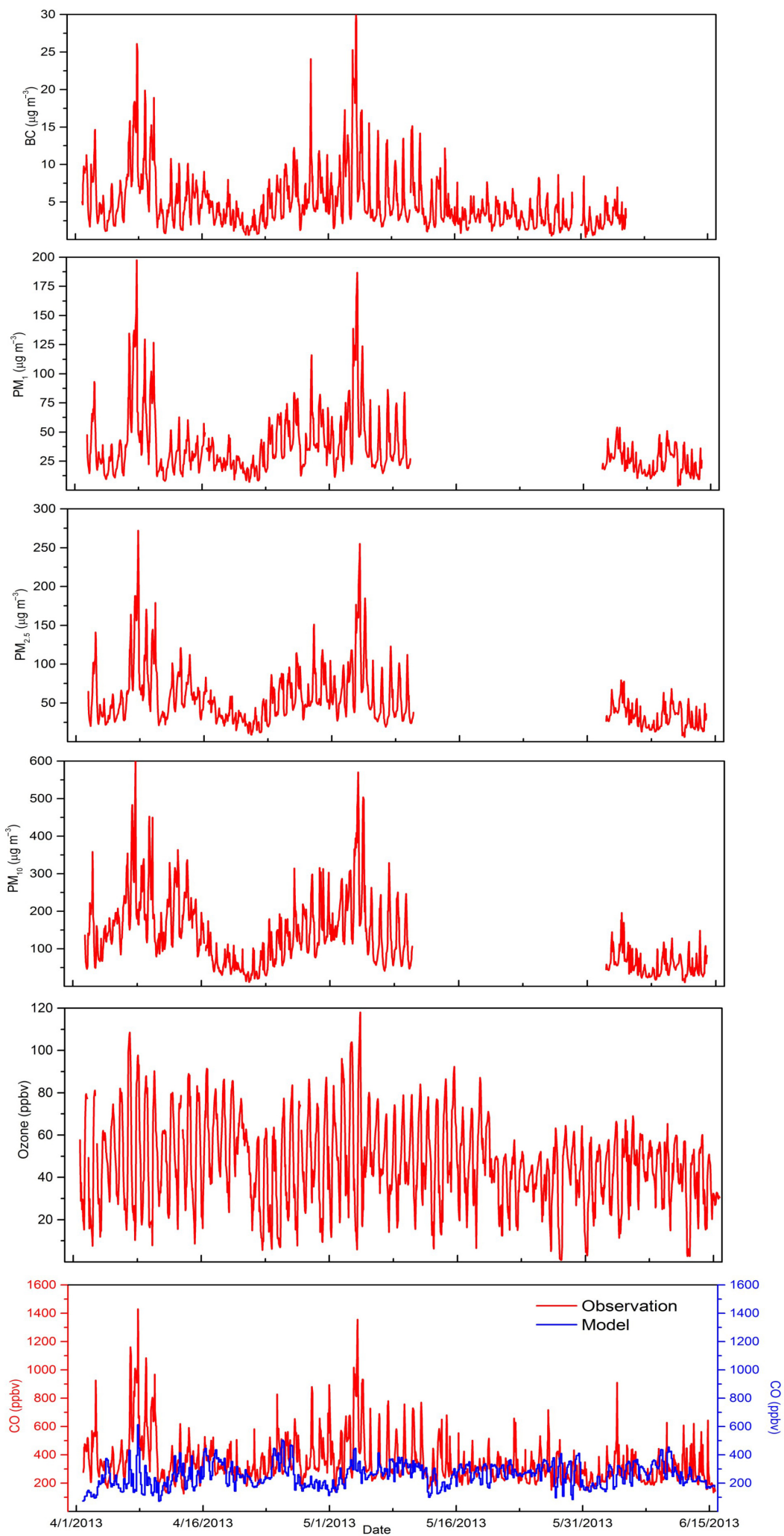

Figure 3. Time series of the observed (red line) and model estimated (blue line) hourly average concentrations of $\mathrm{BC}, \mathrm{PM}_{1}, \mathrm{PM}_{2.5}, \mathrm{PM}_{10}$, $\mathrm{O}_{3}$ and $\mathrm{CO}$ at Lumbini, Nepal, for the entire sampling period from 1 April to 15 June 2013. 


\section{8}

$57 \%$ in Guwahiti (Tiwari et al., 2017), $90 \%$ in Dribugarh (Pathak et al., 2013) and $62 \%$ in Delhi (Tiwari et al., 2015), indicating local differences within IGP as well as suggesting that the influence of combustion sources at Lumbini is still lower compared to other locations in the Indian section of the IGP. A recent study (Putero et al., 2015) reported that the $\mathrm{PM}_{1} / \mathrm{PM}_{10}$ during pre-monsoon of 2013 was found to be 0.39 in the Kathmandu Valley of Nepal. Lumbini has significantly lower vehicle emissions and population than the Kathmandu Valley yet the ratios are similar, indicating the importance of regional combustion sources in Lumbini for finer aerosols $\left(\mathrm{PM}_{1}\right)$ and soil-based emissions such as road dust in the Kathmandu Valley. Future studies will need to explore the emission sources around Lumbini in much greater detail. Lower $\mathrm{PM}_{2.5} / \mathrm{PM}_{10}$ in Lumbini as compared to other regions mentioned earlier could be due to emissions from cement industries located within $15 \mathrm{~km}$ distance from the measurement site.

The observed $24 \mathrm{~h}$ average particulate matter concentrations $\left(\mathrm{PM}_{2.5}\right.$ and $\left.\mathrm{PM}_{10}\right)$ were found frequently higher than the WHO prescribed guidelines for $\mathrm{PM}_{2.5}\left(25 \mu \mathrm{g} \mathrm{m}^{-3}\right)$ and $\mathrm{PM}_{10}\left(50 \mu \mathrm{g} \mathrm{m}^{-3}\right)$ with $\mathrm{PM}_{2.5}$ exceeding $94 \%$ and $\mathrm{PM}_{10}$ of $85 \%$ of the measurement period of 53 days in Lumbini.

Observed CO concentrations ranged between 124.9 and $1429.7 \mathrm{ppbv}$ with an average value of $344.1 \pm 160.3 \mathrm{ppbv}$. $\mathrm{CO}$ concentration observed in Lumbini is lower than that of Mohali, western India, where the average concentration was 566.7 ppbv during pre-monsoon season due to intense biomass and agro-residue burning over the region (Sinha et al., 2014). Temporal variation of $\mathrm{CO}$ concentrations is similar to that of $\mathrm{BC}$, exhibiting very strong correlation $(r=0.9)$. Past studies have shown that the ratio of $\mathrm{BC}$ to $\mathrm{CO}$ depends upon multiple factors like site location, combustion characteristics (fuel and technology) at the sources and type of air mass (Girach et al., 2014; Pan et al., 2011; Zhou et al., 2009). Formation of the soot depends on the carbon-to-oxygen ratio of fuel whereas $\mathrm{CO}$ can also be produced naturally due to the oxidation of volatile organic compounds (Girach et al., 2014). Figure 4 shows the comparison of the average $\triangle \mathrm{BC} / \triangle \mathrm{CO}$ ratio $(0.021)$ at Lumbini with that obtained from other sites. Please refer to Fig. S4 in the Supplement for the time series of $\triangle B C / \triangle C O$ ratio observed in Lumbini. We used the method described by Pan et al. (2011) to calculate the $\triangle B C / \triangle C O$ values. The ratio was calculated using the equation $\left(\mathrm{BC}-\mathrm{BC}_{0}\right) /\left(\mathrm{CO}-\mathrm{CO}_{0}\right)$, assuming the background values $\left(\mathrm{BC}_{0}\right.$ or $\left.\mathrm{CO}_{0}\right)$ as 1.25 percentile of the data. The $\triangle \mathrm{BC} / \triangle \mathrm{CO}$ ratio in Lumbini is similar to that obtained at a suburban site, Pantnagar, in India (0.017) (Joshi et al., 2016) and in Maldives (0.017) (Dickerson et al., 2002), indicating the possibility of similar types of emission sources. However, the lower $\triangle B C / \triangle C O$ ratio obtained over megacities such as Beijing and Shanghai is due to the higher number of gasoline and diesel vehicles (Zhou et al., 2009). The ratios obtained at Lumbini are within the range of emission ratios from diesel used in transport sector
D. Rupakheti et al.: Pre-monsoon air quality over Lumbini

(0.0013-0.055), coal (0.0019-0.0572) and biofuels (0.00870.0266 ) for domestic activities (Verma et al., 2010, and references therein), implying that $\mathrm{BC}$ and $\mathrm{CO}$ observed are from mixed sources.

The hourly averaged observed ozone concentration ranged between 1.0 and $118.1 \mathrm{ppbv}$ with a mean value of $46.6 \pm$ $20.3 \mathrm{ppbv}$ during the sampling period. The $8 \mathrm{~h}$ maximum $\mathrm{O}_{3}$ concentration exceeded WHO guidelines (of $100 \mu \mathrm{g} \mathrm{m}^{-3}$; (WHO, 2006) during $\sim 90 \%$ of the measurement period. Our results clearly indicate that the current pollution levels in Lumbini are of great concern to the health of the people living in the region, including over a million visitors who visit Lumbini, and agro-ecosystems.

The relationship of wind speed to aerosol and gaseous pollutants in Lumbini is shown in Fig. S5 (Supplement). We were interested in studying the relationship between wind speed and the pollutants since the wind governs the horizontal dilution of the pollutants (Huang et al., 2012) and also the likelihood of lifting soil dust. Except ozone, all other pollutants exhibited negative correlation with wind speed. BC shows negative correlation $(r=-0.42, P>0.05)$ with wind speed, which is similar with other pollutants as well (as can be seen from the figure). Past studies have also reported a similar negative correlation of $\mathrm{BC}$ with wind speed over urban and sub-urban areas (Huang et al., 2012; Cao et al., 2009; Ramachandran and Rajesh, 2007; Sharma et al., 2002; Tiwari et al., 2013), indicating that the locally generated $\mathrm{BC}$ can accumulate in the atmosphere during lower wind speed conditions (Cao et al., 2009). Tiwari et al. (2013) also reported similar negative correlation $(r=-0.45)$ during the pre-monsoon season over Delhi. In contrast, secondary pollutants like ozone exhibited a positive relation to the WS $(r=0.38, P>0.05)$, indicating the location of precursor emission sources at some distance away from the measurement site. Solar radiation is one of the most important factors for production of ozone in the atmosphere (Naja et al., 2003). The correlation of hourly ozone concentration with solar radiation (not shown here) was found to be 0.41 $(P>0.05)$, whereas wind speed during the daytime only (06:00-18:00) showed very weak correlation of 0.02 (nonsignificant) with ozone, possibly indicating transport of precursors during nighttime.

Interestingly, the highest concentrations of all measured pollutants were obtained when the wind speed was less than $1 \mathrm{~m} \mathrm{~s}^{-1}$. In a separate analysis (not shown here), we considered only the WS $>1 \mathrm{~m} \mathrm{~s}^{-1}$ and calculated the correlation coefficients to investigate the influence of regional emissions. We found the similar correlation values as previous when all WS values were considered ( $\mathrm{BC}$ vs. $\mathrm{WS}=-0.41, \mathrm{CO}$ vs. $\mathrm{WS}=-0.42, \mathrm{O}_{3}$ vs. $\mathrm{WS}=0.29, \mathrm{PM}_{1}$ vs. $\mathrm{WS}=-0.40$, $\mathrm{PM}_{2.5}$ vs. WS $=-0.38, \mathrm{PM}_{10}$ vs. $\mathrm{WS}=-0.33$; all at $P>$ $0.05)$. The correlation of WS $\left(>1 \mathrm{~m} \mathrm{~s}^{-1}\right)$ with concentration of air pollutants indicates that air pollution over Lumbini is not only of local origin but also from other nearby regions. 


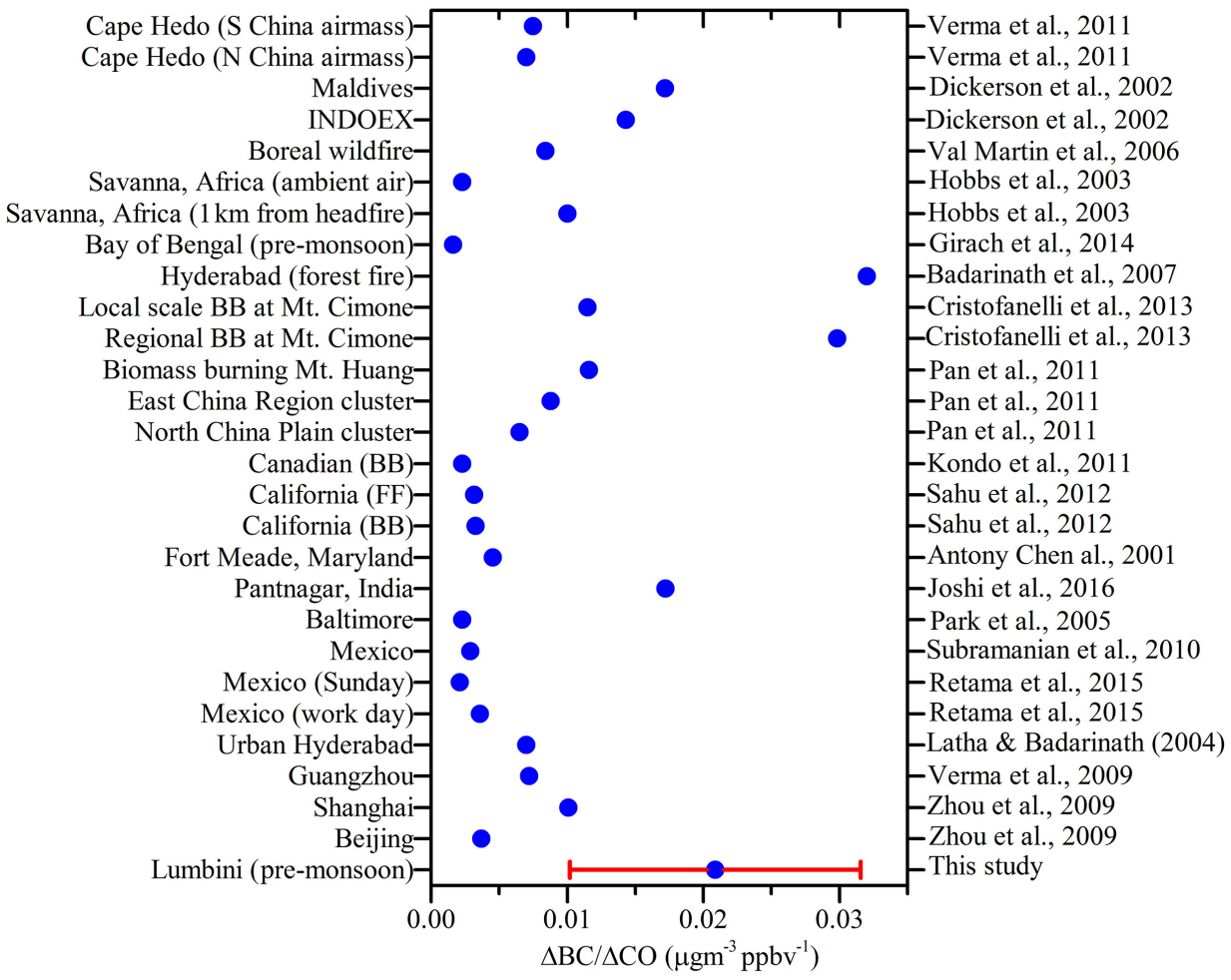

Figure 4. Comparison of black carbon concentrations to $\mathrm{CO}$ concentrations $(\Delta \mathrm{BC} / \Delta \mathrm{CO})$ ratios obtained for Lumbini with other sites. The red horizontal bar represents SD.

Past studies near this site have been focused on cities like Kathmandu (Sharma et al., 2012; Panday and Prinn, 2009; Putero et al., 2015) and Kanpur (Ram et al., 2010) and regions of IGP dominated by agro-residue burning (Rastogi et al., 2016; Sinha et al., 2014; Sarkar et al., 2013), all of which reported very high levels of pollution. Our study adds to the growing list of scientific observations in the IGP by providing data from the foothills of the central Himalayas. Very high aerosol loading is observed in South Asia during pre-monsoon, mostly over the IGP region (Supplement, Fig. S6). As this is the first study over an IGP site located in Nepal, pollution concentrations observed at Lumbini were compared with other sites in the region (Table 2). Different sites located at urban, semi-urban and remote locations were used for comparison to get a clear comparative picture of the situation at Lumbini amongst other locations in the region. Pre-monsoon seasonal average $\mathrm{PM}_{2.5}$ concentration in Lumbini has been found to be lower than in the megacity Delhi (Bisht et al., 2015) and northwestern IGP (Sinha et al., 2014), possibly due to higher levels of emissions (from traffic and biomass burning, respectively) over those regions. In addition, average $\mathrm{BC}$ and $\mathrm{CO}$ concentrations in Lumbini fell between concentrations observed at rural sites (up to 6 times higher) and cities in the region (see Table 2), indicating that Lumbini, in a way, can still be considered a semi-urban location. The hourly average $\mathrm{O}_{3}$ concentrations in Lumbini were found to be higher than in cities like Kathmandu (Putero et al., 2015) and Kanpur during the pre-monsoon season (Gaur et al., 2014). However from a mesoscale perspective, the hourly average $\mathrm{O}_{3}$ concentrations were lower at Lumbini as compared to the base camp of Mount Everest region due to the uplift of polluted air masses (Marinoni et al., 2013), stratospheric intrusion (Cristofanelli et al., 2010) and even the regional or long-range transport of the air pollutants (Bonasoni et al., 2010) to the high-altitude site.

Regarding the monthly average concentration, the concentrations of all measured pollutants decreased as the premonsoon months advanced. The monthly average concentrations of the monitored species are shown in Fig. S7 along with the monthly fire hotspots over the region. Reduction in concentration (except PM) during the month of May (as compared to April) could be attributed to the fewer fire events during May as well as previously discussed washout by rainfall. Two peak pollution episodes observed during the first half of April and May are discussed in more detail in the next section.

\subsubsection{Observation-model intercomparison}

Chemical transport models provide insight to observed phenomena; however, interpretation has to take into account model performance before arriving at any conclusion. This section describes pollution concentrations simulated by the 
Table 2. Comparison of $\mathrm{PM}_{2.5}, \mathrm{BC}, \mathrm{CO}$ and $\mathrm{O}_{3}$ concentrations at Lumbini with those at other sites in South Asia.

\begin{tabular}{|c|c|c|c|c|c|c|c|}
\hline Sites & Characteristics & $\begin{array}{l}\text { Measurement } \\
\text { period }\end{array}$ & $\begin{array}{l}\mathrm{PM}_{2.5} \\
\left(\mu \mathrm{g} \mathrm{m}^{-3}\right)\end{array}$ & $\begin{array}{l}\mathrm{BC} \\
\left(\mu \mathrm{gm}^{-3}\right)\end{array}$ & $\begin{array}{l}\mathrm{CO} \\
\text { (ppbv) }\end{array}$ & $\begin{array}{l}\mathrm{O}_{3} \\
(\mathrm{ppbv})\end{array}$ & References \\
\hline Lumbini, & Semi-urban & Pre-monsoon, 2013 & $53.1 \pm 35.1$ & $4.9 \pm 3.8$ & $344.1 \pm 160.3$ & $46.6 \pm 20.3$ & This study \\
\hline Kathmandu, Nepal & Urban & Pre-monsoon, 2013 & - & $14.5 \pm 10$ & - & $38.0 \pm 25.6$ & Putero et al. (2015) \\
\hline Mount Everest, Nepal & Remote & Pre-monsoon & - & $0.4 \pm 0.4$ & - & $61.3 \pm 7.7$ & Marinoni et al. (2013) \\
\hline Delhi, India & Urban & $\begin{array}{l}\text { Pre-monsoon } \\
\text { (nighttime) }\end{array}$ & $82.3 \pm 50.5$ & $7.70 \pm 7.25$ & $1800 \pm 890$ & - & Bisht et al. (2015) \\
\hline Kanpur, India & Urban & $\begin{array}{l}\text { June 2009-May } \\
\text { 2013, April-Jun }\end{array}$ & - & $2.1 \pm 0.9$ & $721 \pm 403$ & $27.9 \pm 17.8$ & $\begin{array}{l}\text { Gaur et al. (2014) } \\
\text { Ram et al. (2010) }\end{array}$ \\
\hline Mohali, India & Semi-urban & May 2012 & $104 \pm 80.3$ & - & $566.7 \pm 239.2$ & $57.8 \pm 25.4$ & Sinha et al. (2014) \\
\hline Mount Abu, India & Remote & $\begin{array}{l}\text { January } 1993- \\
\text { December } 2000 \text {, } \\
\text { pre-monsoon }\end{array}$ & - & $0.7 \pm 0.14$ & $131 \pm 36$ & $39.9 \pm 10.8$ & $\begin{array}{l}\text { Naja et al. (2003) } \\
\text { Das and Jayaraman (2011) }\end{array}$ \\
\hline
\end{tabular}

WRF-STEM model. A comparison of model calculated pollutant concentration along with the minimum and maximum concentrations of various pollutants (with observation) is shown in Table 3. The model-based concentrations used here are values outputted for every third hour of the day (actual computation is carried out every $15 \mathrm{~min}$ ). $\mathrm{BC}$ concentrations ranged between 0.4 and $3.7 \mu \mathrm{g} \mathrm{m}^{-3}$ with a mean value of $1.8 \pm 0.7 \mathrm{\mu g} \mathrm{m}^{-3}$ for the period of 1 April15 June 2013. The average model BC concentration was $\sim 2.7$ times lower than the observed BC. Regarding $\mathrm{PM}_{1}$, $\mathrm{PM}_{2.5}$ and $\mathrm{PM}_{10}$, the model-simulated average concentration was $12.3 \pm 5.5(0.9-41.7), 17.3 \pm 6.7(1.9-48.3)$ and $25.4 \pm 12.9(2.1-68.8) \mu \mathrm{g} \mathrm{m}^{-3}$, respectively. The model estimated values were lower by a factor of 3 and 5, respectively, than the observed concentrations. The data show that the model needs much improvement in its ability to adequately predict observed aerosol characteristics at Lumbini given the input provided, e.g., emissions data. Since pollutant concentration is a function of emissions, transport, transformation and deposition, improvements in any of these areas would improve the model performance for this site. However, given observation insights by PM ratios, it seems that improvements are much needed in the emissions of primary aerosols. Current emissions (2010) do not account for trash burning, roadside dust and increasingly newer industries, especially emissions from cement factories that have popped up in recent years. We show sensitivity with emissions in a later section (Sect. 3.3.2) in the vicinity of Lumbini, but emission improvements are needed beyond Lumbini, which is outside the scope of this paper.

Average observed CO concentration was $255.7 \pm$ $83.5 \mathrm{ppbv}$, ranging between 72.2 and $613.1 \mathrm{ppbv}$, with average model $\mathrm{CO} \sim 1.35$ times lower than observed. Time series comparison of modeled $\mathrm{CO}$ vs. observation is shown in Fig. 3. Apart from two peak episodes the model does a better job in predicting $\mathrm{CO}$ concentration over Lumbini. A previous study using STEM over Kathmandu Valley showed that the model was able to capture the annual BC mean value but completely missed the concentrations during pre-monsoon and post-monsoon period (Adhikary et al.,
2007). Similar behavior is seen this time for $\mathrm{CO}$ where the model misses the peak values but reasonably captures $\mathrm{CO}$ concentration after mid-May when no biomass burning events are observed (model to observation ratio improves to 1.16). STEM CO performance can be significantly improved via better constraining emissions of open biomass burning as discussed in Sect. 3.3. This activity is beyond the scope of this current paper although improvements are underway for all these sectors.

\subsubsection{Diurnal variations of air pollutants and boundary layer height}

In the emission source region, diurnal variations of primary pollutants provide information about the time-dependent emission activities (Kumar et al., 2016b). Figure 5 shows the diurnal variation of hourly averaged concentrations of measured pollutants during the sampling period. Primary pollutants like BC, PM and CO showed typical characteristics of an urban environment, i.e., diurnal variation with a morning and an evening peak. However, Lumbini data show higher concentrations in the evenings compared to morning hours. Elevated concentrations can be linked to morning and evening cooking hours for $\mathrm{BC}$ and $\mathrm{CO}$. Emission inventories for the region show that the residential sector has significant contribution to $\mathrm{BC}$ and $\mathrm{CO}$. However, an explanation for the elevated evening concentration compared to the morning is needed. Increase in the boundary layer height, reduction in the traffic density on the roads, absence of cooking activities during mid-day and increase in wind speed often contribute to the dispersion of pollutants, resulting in lower concentrations during the afternoon. Diurnal variation of wind direction (Supplement, Fig. S2, upper panel) shows the dominance of wind coming from the south (mainly during the month of May until mid-June). Morning and evening periods experienced the winds coming from the southeastern direction while the winds were predominantly from the southwestern direction during late afternoon. The increase in $\mathrm{CO}$ concentrations in the evening hours might be due to transport of $\mathrm{CO}$ from source regions upwind of Lumbini, which, along 
Table 3. Intercomparison of observed and model-simulated hourly average concentrations of air pollutants during the measurement campaign

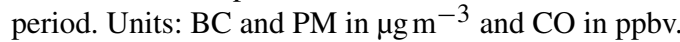

\begin{tabular}{llll}
\hline Pollutants & $\begin{array}{l}\text { Observed } \\
\text { (mean and range) }\end{array}$ & $\begin{array}{l}\text { Modeled } \\
\text { (mean and range) }\end{array}$ & $\begin{array}{l}\text { Ratio of mean } \\
\text { (observed/modeled) }\end{array}$ \\
\hline $\mathrm{BC}$ & $4.9(0.3-29.9)$ & $1.8(0.4-3.7)$ & 2.7 \\
$\mathrm{PM}_{1}$ & $36.6(3.6-197.6)$ & $12.3(0.9-41.7)$ & 3 \\
$\mathrm{PM}_{2.5}$ & $53.1(6.1-272.2)$ & $17.3(1.9-48.3)$ & 3 \\
$\mathrm{PM}_{10}$ & $128.8(10.5-604.0)$ & $25.4(2.1-68.8)$ & 5 \\
$\mathrm{CO}$ & $344.1(124.9-1429.7)$ & $255.7(72.2-613.1)$ & 1.35 \\
\hline
\end{tabular}

with the local emissions, get trapped under reduced planetary boundary layer (PBL) heights. Ozone concentration was lowest in the morning before the sunrise and highest in late afternoon around 15:00 after which concentrations started declining, exhibiting a typical characteristic of a polluted urban site. Photo-dissociation of accumulated $\mathrm{NO}_{x}$ reservoirs (like HONO) provides sufficient NO concentration, leading to the titration of $\mathrm{O}_{3}$ and resulting in minimum $\mathrm{O}_{3}$ just before sunrise (Kumar et al., 2016b). The PBL height (in meters) was obtained from the WRF model as observations were not available. The study period's average PBL height over Lumbini was $\sim 910 \mathrm{~m}$ (ranging between 24 and $3807 \mathrm{~m}$, observed at 06:00 and 15:00, respectively). The daily average PBL height obtained from the model is compared with published values (Wan et al., 2017), as shown in Fig. 6, which indicate that the value is captured by our model during initial measurement period and overestimated in the months of midMay onwards. As the pre-monsoon month advances, PBL height also increased. The monthly average PBL height was 799, 956 and $1014 \mathrm{~m}$, respectively, during the month of April, May and (1-15) June. As presented in the figure, the monthly average diurnal variation also showed that the boundary layer height was at its maximum at 15:00 LT during each month, which coincides with the period of lowest concentration of the pollutants.

\subsection{Influence of forest fires on Lumbini air quality}

\subsubsection{Identification of large-scale forest fire influence using in situ observations, satellite and model data}

Forest fires and agricultural biomass burning (mostly agroresidue burning on a large scale) are common over South Asia and the IGP region during pre-monsoon season. The northern Indo-Gangetic region is characterized by fires even during the monsoon and post-monsoon season (Kumar et al., 2016b; Putero et al., 2014). These activities not only influence air quality over nearby regions but also get transported towards high-elevation pristine environments like Mount Everest (Putero et al., 2014) and Tibet (Cong et al., 2015a,b). Thus, one of the main objectives of this study was to identify the influence of open burning on Lumbini air quality. Aver- age wind speed during the whole measurement period was $2.4 \mathrm{~m} \mathrm{~s}^{-1}$. Based on these data, open fire counts within the grid size of $200 \times 200 \mathrm{~km}$ centering over Lumbini were used for this analysis, assuming that the emissions would take a maximum period of 1 day to reach our monitoring site. Forest fire counts were obtained from the MODIS satellite data product Fire Information for Resource Management System (FIRMS). Figure 7 shows the daily average $\triangle B C / \Delta C O$ ratio, aerosol absorption Ångström exponent (AAE), which is derived from Aethalometer data (by calculating the negative slope of absorption at 370 and $950 \mathrm{~nm}$ vs. wavelength in log-log plot), and daily open fire counts within the specified grid. The green box in the figure is used to show two peak events (presented earlier in Fig. 3) with the elevated $\mathrm{BC}$ and $\mathrm{CO}$ concentrations observed during the monitoring period. The first peak was observed during 7-9 April and second peak during 3-4 May 2013. Two pollutants having biomass burning as the potential primary source, $\mathrm{BC}$ and $\mathrm{CO}$, were taken in consideration. High AAE values during these two events are also an indication of the presence of BC of biomass burning origin (Praveen et al., 2012; Bergstrom et al., 2007; Kirchstetter et al., 2004), with the value being $\sim 1.6$ for Lumbini. The chemical composition of TSP filter samples collected at Lumbini also showed higher concentration of Levoglucosan, a biomass burning tracer in Lumbini during the pre-monsoon season, compared to other seasons of the year (Wan et al., 2017). Wan et al. (2017) also reported that the higher correlation of $\mathrm{K}^{+}$with $\mathrm{Ca}^{2+}$ and $\mathrm{Mg}^{2+}$ indicates that dust is the main source of potassium in Lumbini.

Contrary to our expectation, we could not observe any significant influence of forest fire within the specified grid of $200 \times 200 \mathrm{~km}$ (the influence of local forest fire on the air quality over Lumbini was not observed). Therefore, a wider area, covering South and Southeast Asia, was selected for the forest fire count. Figure $8 \mathrm{a}$ and $\mathrm{b}$ show the active fire hotspots from MODIS over the region during the peak events, indicating the first peak could have occurred due to the forest fire over the eastern India region whereas the second peak was influenced by the forest fire over the western IGP. Moreover, in order to strengthen our hypothesis, we have utilized satellite data products for various gaseous pollutants like $\mathrm{CO}$ and $\mathrm{NO}_{2}$ (Atmospheric Infrared Sounder (AIRS) for CO and 

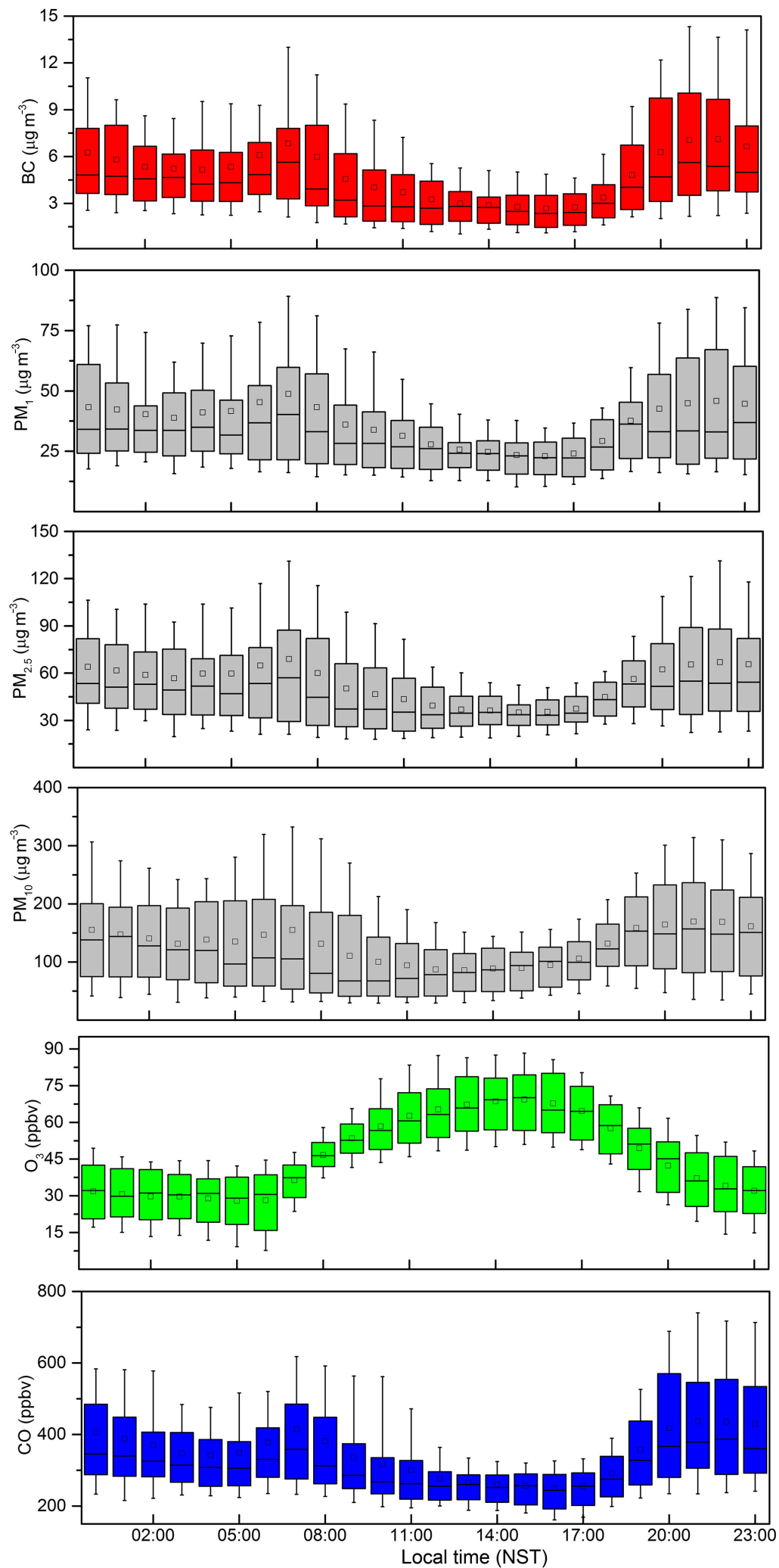

Figure 5. Diurnal variations of hourly average ambient concentrations of $\mathrm{BC}, \mathrm{PM}_{1}, \mathrm{PM}_{2.5}, \mathrm{PM}_{10}, \mathrm{O}_{3}$ and $\mathrm{CO}$ at Lumbini during the monitoring period (1 April-15 June 2013). In each box, the lower and upper boundary of the box represent the 25th and 75th percentile, respectively; the top and bottom of the whisker represent the 90th and 10th percentile, respectively; the mid-line represents the median; and the square mark represents the mean for each hour. 

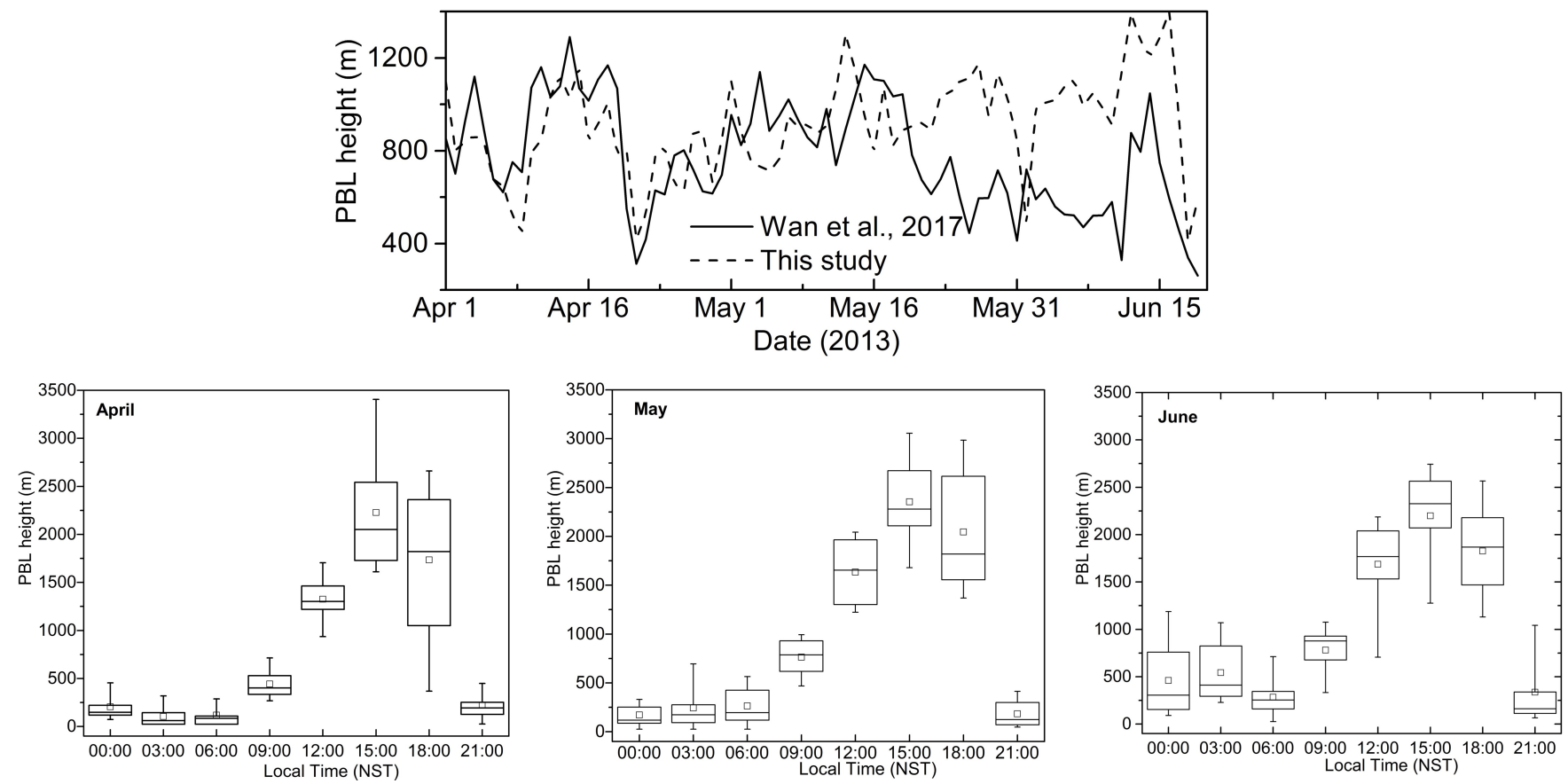

Figure 6. Daily time series of PBL height obtained from the model and reported values over Lumbini (obtained from Wan et al., 2017). The lower panel shows the monthly average diurnal variation of the PBL height. The square mark in each box represents the mean PBL height, the bottom and top of the box represent the 25th and 75th percentile and the top and bottom of the whisker represent the 90 th and 10th percentile, respectively.

Ozone Monitoring Instrument (OMI) for $\mathrm{NO}_{2}$, both obtained from Giovanni platform). Figure 8c-h show the daytime total column $\mathrm{CO}$ before, during and after occurrence of two events (peaks), as stated earlier. The AIRS satellite with daily temporal resolution and $1^{\circ} \times 1^{\circ}$ spatial resolution has been utilized to understand the $\mathrm{CO}$ concentration over the area. $\mathrm{CO}$ concentration over Lumbini during both of the peaks confirmed the role of open fires over the IGP region for elevated concentration of $\mathrm{CO}$ in Lumbini. To further strengthen our finding, HYSPLIT back-trajectory plots were used. Figure $8 \mathrm{i}$ and $\mathrm{j}$ represent the 6-hourly back trajectories for these two events only. However, the back trajectories (during both events) indicated that the air mass passed over the fire events in the northwestern IGP. We note that using back trajectories to identify source regions is also uncertain, as noted by Jaffe et al. (1997). Figure 8k shows model biomass CO peak coincident with observed $\mathrm{CO}$. Although the magnitudes are significantly different, the timing of the peaks is captured well by the model. This, we believe, is due to the fact that satellitebased open fire detection has limitations because it cannot capture numerous small fires that are prevalent over South Asia but usually burn out before the next satellite overpass. More research is needed to assess the influence of these small fires on regional air quality.

In a separate analysis (not shown here), elevated $\mathrm{O}_{3}$ concentrations during these two events were also observed. The average $\mathrm{O}_{3}$ concentration before, during and after the events was found to be $46.2 \pm 20.3,53.5 \pm 31.1$ and $50.3 \pm 20.9 \mathrm{ppbv}$, respectively (Event I), and $54.8 \pm 23.8,56.7 \pm 35$ and $55.6 \pm$ $13.4 \mathrm{ppbv}$, respectively (Event II). Average ozone concentration outside these events was found to be $46 \pm 19$ ppbv. Increased ozone concentrations during the high peak events have been analyzed using the satellite $\mathrm{NO}_{2}$ concentration over the region and considering the role of $\mathrm{NO}_{2}$ as a precursor for ozone formation. Daily total column $\mathrm{NO}_{2}$ was obtained from the OMI satellite (data available at the Giovanni platform; http://giovanni.gsfc.nasa.gov/giovanni/) at the spatial resolution of $0.25^{\circ} \times 0.25^{\circ}$. Figure 9 shows the $\mathrm{NO}_{2}$ column value before, during and after both events. Even for the $\mathrm{NO}_{2}$, maximum concentrations were observed during these two special events. It is likely that both local and regional pollution (transported from NW IGP region as indicated by synoptic wind in Fig. S8, Supplement) contributed to the elevated ozone levels. This remains a question to be investigated in future.

\subsubsection{Identifying regional and local contribution}

The WRF-STEM model has been used to identify the anthropogenic emission source region influencing the air quality over Lumbini. As previously explained, the model is able to capture the observed $\mathrm{CO}$ concentration when intense open burning events were not present. A recent study (Kulkarni et al., 2015) has explored the source region contribution of 


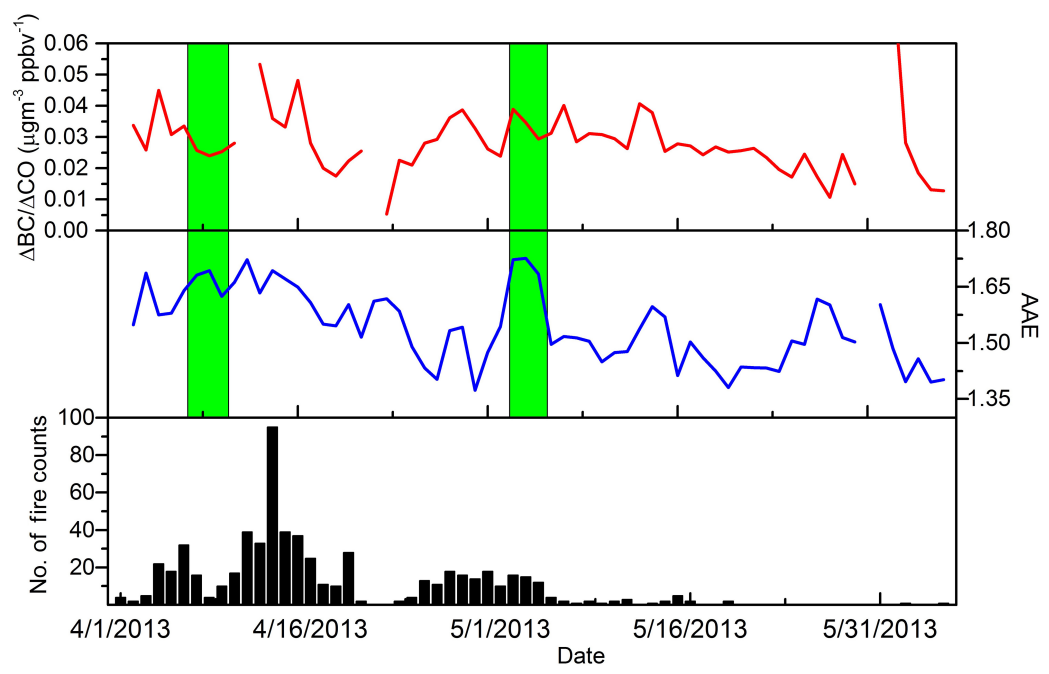

Figure 7. Time series of daily average $\triangle \mathrm{BC} / \triangle \mathrm{CO}$ ratio, absorption Ångström exponent (AAE) and fire counts acquired with the MODIS instrument on board the TERRA satellite for a $200 \times 200 \mathrm{~km}$ grid centered at Lumbini. Two rectangular green boxes represent time of two episodes with high peaks in $\mathrm{CO}$ and $\mathrm{BC}$ concentrations as shown in Fig. 3.

various pollutants over central Asia using similar technique. Figure 10a shows the average contribution from different regions to $\mathrm{CO}$ concentration over Lumbini during the whole measurement period. The major share of $\mathrm{CO}$ was from the Ganges Valley (46\%), followed by the Nepal region (25\%) and the rest of India $(\sim 17.5 \%)$. Contributions from other South Asian countries like Bangladesh and Pakistan were $\sim 11 \%$ whereas China contributed $\sim 1 \%$ of the $\mathrm{CO}$ concentration in Lumbini. Regarding the monthly average contribution, Ganges Valley's and Nepal's contributions were almost equal during the month of April ( $\sim 34$ and $\sim 37 \%$ respectively) but increased for the Ganges Valley during the month of May $(\sim 44 \%)$ and were reduced for Nepal $(\sim 25 \%)$ (Fig. S9, Supplement).

Figure $10 \mathrm{~b}$ is the time series of percentage contribution to total $\mathrm{CO}$ concentration during the whole measurement period, showing different air masses arriving at 3-hourly intervals. During the whole measurement period, the majority of the $\mathrm{CO}$ reaching Lumbini was from the Ganges Valley (mainly the states of Punjab, Haryana, Uttar Pradesh, Bihar and West Bengal) region with the contribution sometimes reaching up to $\sim 80 \%$. Other Indian (central, south, east and north) regions also contributed significantly. Bangladesh's contribution of CO loading was seen only after mid-April, lasting for only about a week and after the first week of May. The contribution from Bangladesh was sporadic compared to other regions. The highest contribution from Bangladesh was observed after the first week of June with the arrival of monsoonal air mass. Pakistan also contributed to the CO loading significantly. Others region as mentioned in the figure covered the regions like Afghanistan, the Middle East, western Asia, East Asia, Africa and Bhutan. Contributions from these regions were less than $5 \%$. Contribution from China was not evident until the first week of June where a specific air-mass arrival shows contribution reaching up to $25 \%$ of total $\mathrm{CO}$ loading.

A sensitivity analysis was performed for emission uncertainty in the model grid containing Lumbini. Lumbini and surrounding regions in the recent years have seen significant rise in urban activities and industrial activity and related emissions which may not be accurately reflected in the HTAP v2 emissions inventory. A month-long simulation was carried out with emissions from Lumbini and by switching off the four grids surrounding Lumbini, and another simulation with Lumbini and the surrounding four grids' emissions increased by 5 times the amount of HTAP v2 emissions inventory. The results are shown in Fig. 10c as percentage increase or decrease compared to model results using the current HTAP v2 emissions inventory. The black line shows the concentration as $100 \%$ for the current HTAP v2 emissions inventory. Despite making Lumbini and the surrounding grids emissions zero, model calculation shows pollutant concentration on average is still about $78 \%$ of the original value, indicating dominance of the background and regional sources compared to the local source in the model. Increasing emissions 5 times for Lumbini and surrounding four grids only increases the concentration on average by $151 \%$. Thus uncertainty in emissions is not a local uncertainty for Lumbini but rather for the whole region, which needs to be better understood for improving model performance against observations at Lumbini.

\subsection{Does fossil fuel or biomass influence Lumbini air?}

The aerosol spectral absorption is used to gain insight into nature and potential source of black carbon. This method 

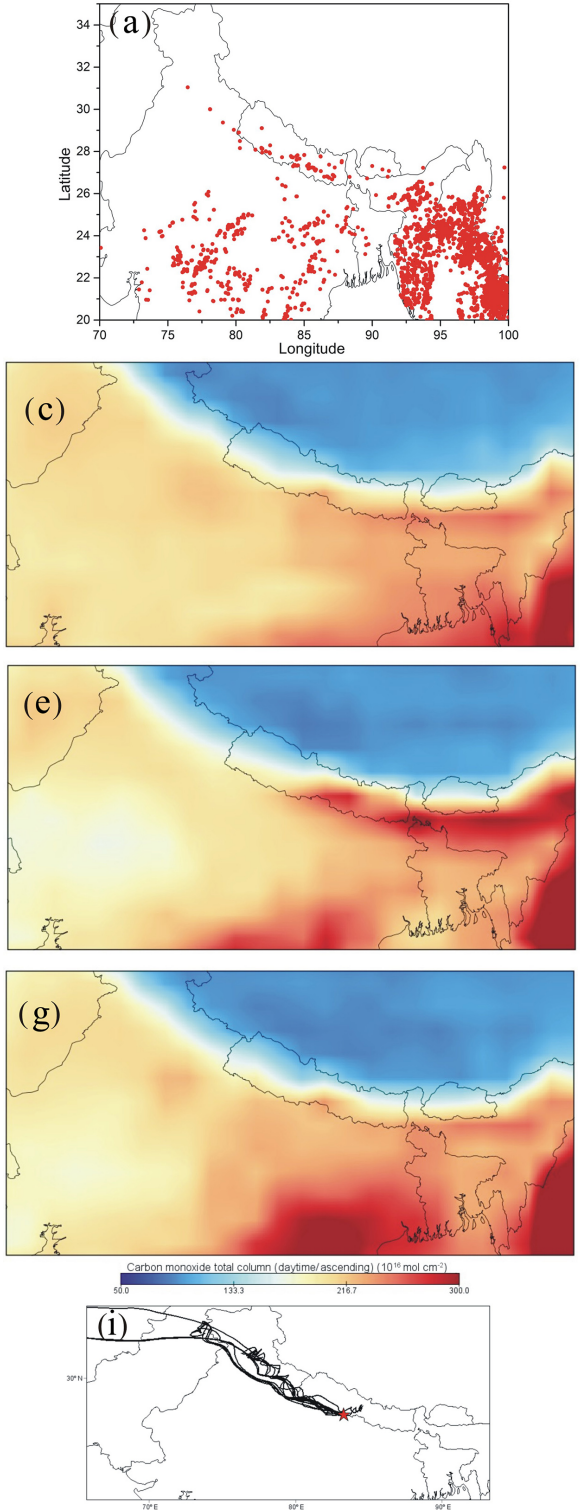
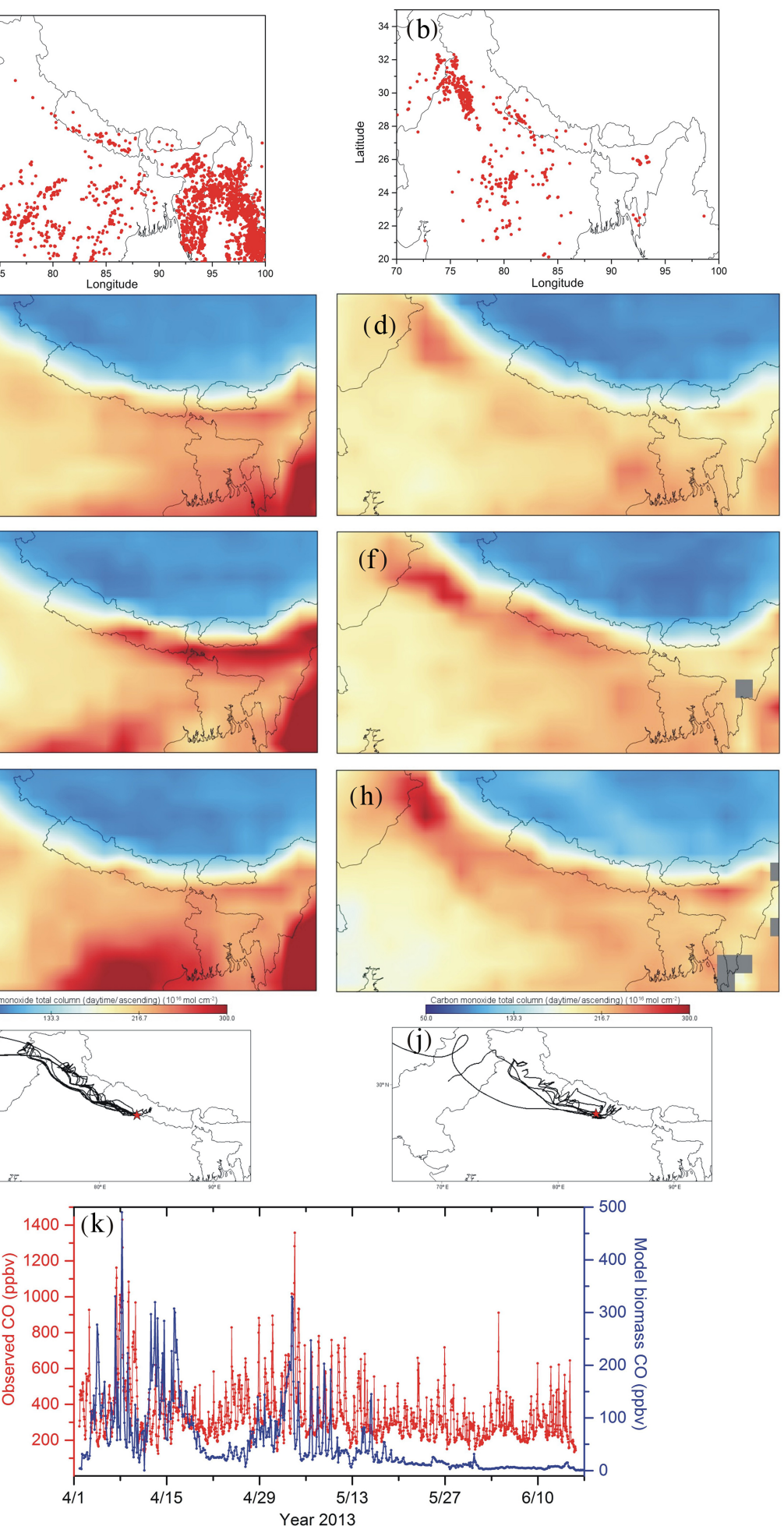

Figure 8. Active fire hotspots in the region acquired with the MODIS instrument on Aqua satellite during (a) Event I (7-9 April) and (b) Event II (3-4 May). CO emissions, acquired with AIRS satellite, in the region 2 days before (3-5 April), during (7-9 April) and 2 days after (10-12 April) the Event I are shown in panels (c, e, $\mathbf{g})$, respectively, while panels (d, f, h) show CO emissions 2 days before (1-2 May), during (3-4 May) and 2 days after (5-6 May) the Event II. Panels (i, j) represent the $6 \mathrm{~h}$ interval HYSPLIT back trajectories during Event I and II, respectively. Location of the Lumbini site is indicated by the red star in the panels (i, $\mathbf{j})$. Observed CO vs. model open burning CO illustrating the contribution of forest fires during peak $\mathrm{CO}$ loading is shown in panel (k). 

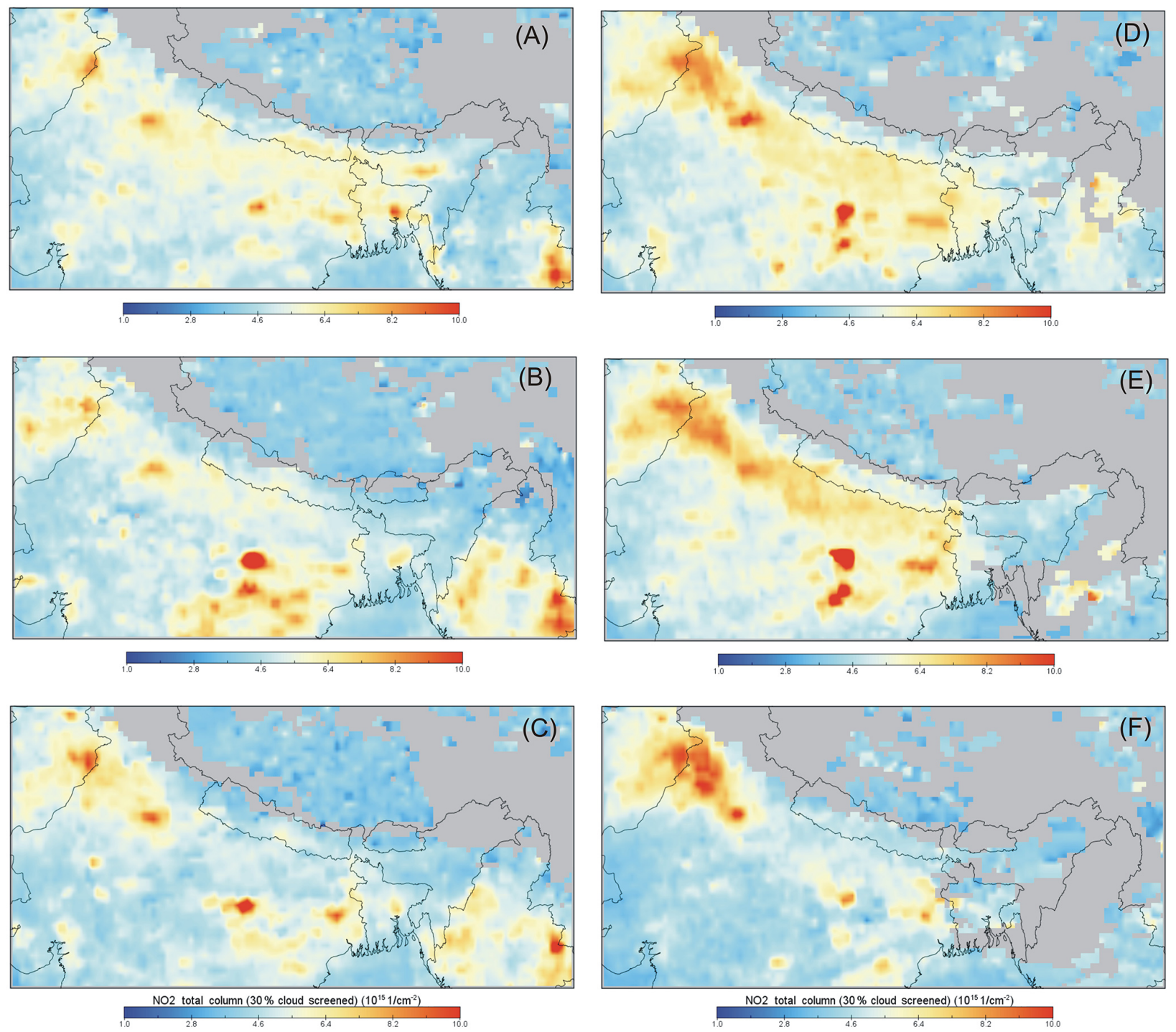

Figure 9. $\mathrm{NO}_{2}$ total column obtained with OMI satellite over the region (a) before, (b) during and (c) after Event I. The panels (d-f) show $\mathrm{NO}_{2}$ total column before, during and after Event II.

enables to analyze the contributions of fossil fuel combustion and biomass burning contributions to the observed $\mathrm{BC}$ concentration (Kirchstetter et al., 2004). Besides BC, other light absorbing (in the UV region) aerosols are also produced in course of combustion, collectively termed organic aerosols (often also called brown carbon) (Andreae and Gelencsér, 2006). Figure 11 shows the comparison of normalized light absorption as a function of the wavelength for $\mathrm{BC}$ observed at Lumbini during cooking and non-cooking hours and also for both events. Our results are compared with the published data of Kirchstetter et al. (2004) and that observed over a village site of Project Surya in the IGP (Praveen et al., 2012) (figure not shown). We discuss light absorption data from two distinct times of the day. The main reason behind using data from 07:00-08:00 and 16:00-17:00 is these periods represent highest and lowest ambient concentration (Fig. 5). Also these periods represent cooking (07:0008:00) and non-cooking (16:00-17:00) or high and low vehicular movement hours (Praveen et al., 2012). To understand the influence of biomass and fossil fuel we plotted normalized aerosol absorption at $700 \mathrm{~nm}$ wavelength for complete Aethalometer-measured wavelengths in Fig. 11. Kirchstetter et al. (2004) reported OC absorption efficiency at $700 \mathrm{~nm}$ to be zero. Thus we normalized measured absorption spectrum by $700 \mathrm{~nm}$ wavelength absorption. Since the Aethalometer does not provide $700 \mathrm{~nm}$ wavelength absorption values, we calculated the value using the absorption at nearby wavelengths and Ångström exponent following the methodology used by Praveen et al. (2012). Our results show that the normalized absorption for biomass burning aerosol is $\sim 3$ 


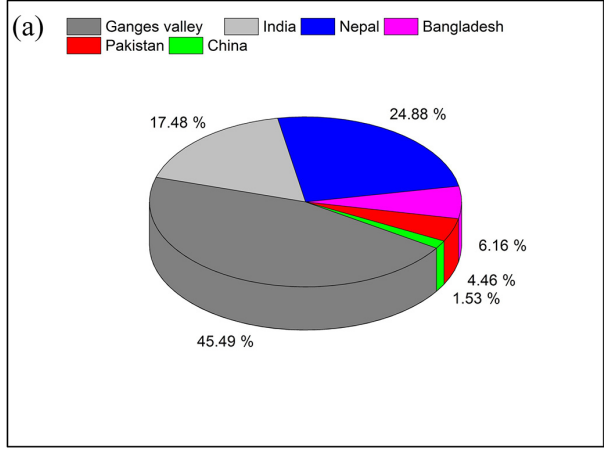

(b) Region tagged $\mathrm{CO}$ tracers
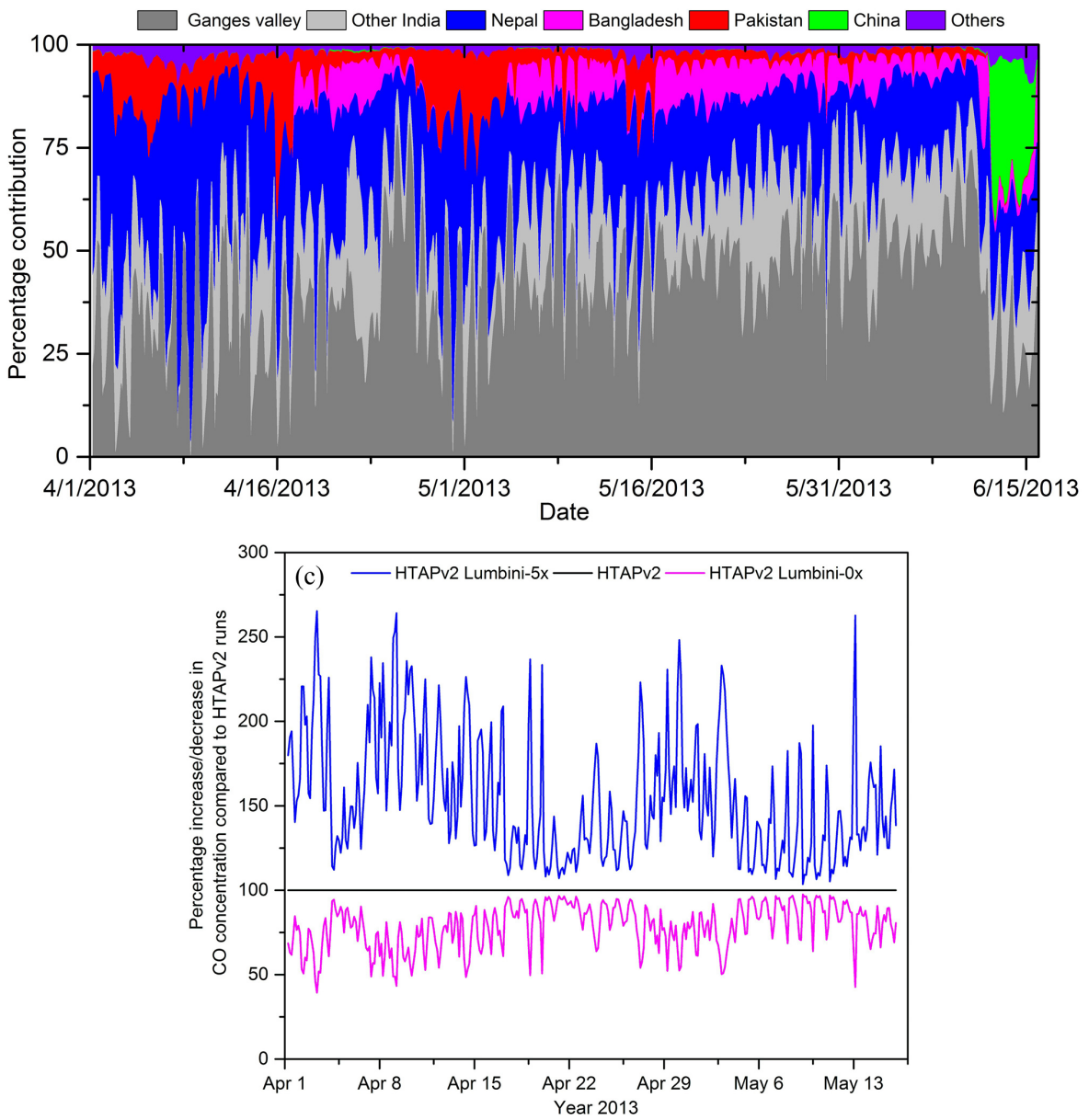

Figure 10. (a) WRF-STEM model estimated contributions of various source regions to average $\mathrm{CO}$ concentration in Lumbini for the sampling period; (b) time series of regionally tagged $\mathrm{CO}$ tracer during the whole measurement period using HTAP emission inventory; (c) percentage increase and decrease in $\mathrm{CO}$ concentration with different emissions scenario.

times higher at $370 \mathrm{~nm}$ than that at $700 \mathrm{~nm}$ whereas fossil fuel absorption is about 2.6 times higher at the same wavelength. In addition, the curve obtained for the both events is inclined towards the published biomass burning curve. The normalized curve obtained during both cooking and noncooking period lies in between the standard curve of Kirchstetter et al. (2004). As shown in Fig. 11, the curve obtained for the prime cooking time is closer to the published curve on biomass burning whereas that obtained during the noncooking time is closer to the published fossil fuel curve. Similar results were also observed over the Project Surya village in the IGP region (Praveen et al., 2012; Rehman et al., 2011). This clearly indicates there is contribution from both sources, 


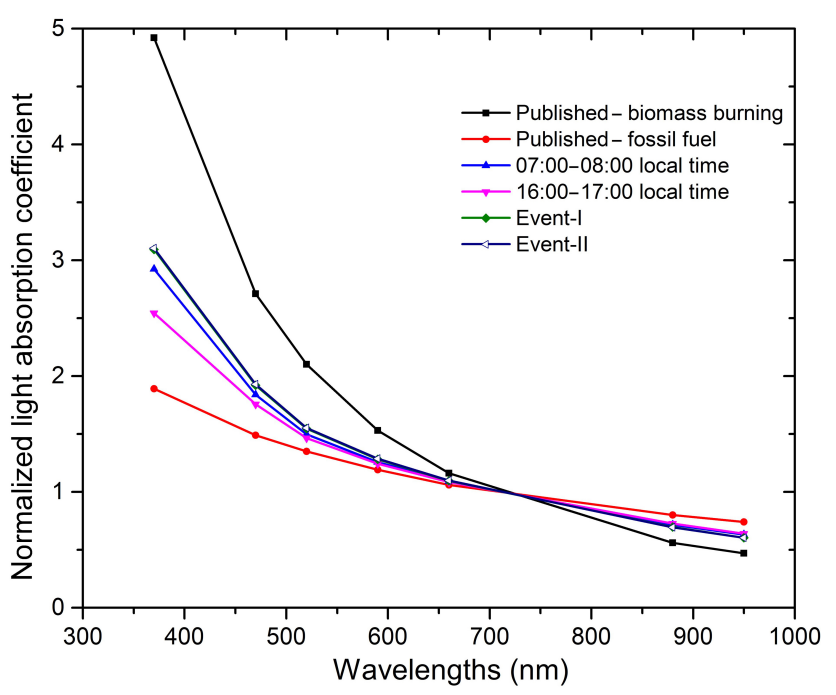

Figure 11. Comparison of normalized spectral light absorption coefficients obtained during the prime cooking (07:00-08:00 LT) and non-cooking time (16:00-17:00 LT) at Lumbini with published data from Kirchstetter et al. (2004).

biomass and fossil fuel, to the observed $\mathrm{BC}$ concentration over Lumbini.

In order to identify fractional contribution of biomass burning and fossil fuel combustion to observed BC aerosol, we adopted the method described by Sandradewi et al. (2008). Wavelength dependence of aerosol absorption coefficient $\left(b_{\mathrm{abs}}\right)$ is proportional to $\lambda^{-\alpha}$, where $\lambda$ is the wavelength and $\alpha$ is the absorption AAE. The $\alpha$ values ranges from 0.9 to 2.2 for fresh wood smoke aerosol (Day et al., 2006) and between 0.8 and 1.1 for traffic or diesel soot (references in Sandradewi et al., 2008). We have taken an $\alpha$ value of 1.86 for biomass burning and 1.1 for fossil fuel burning as suggested by previous literature (Sandradewi et al., 2008). Figure 12 shows diurnal variation of the biomass burning BC. Minimum contribution of biomass burning to total BC concentration was observed during 04:00-06:00 LT (only about $30 \%$ of the total $\mathrm{BC}$ ). As the cooking activities start in morning, the contribution of biomass BC starts to increase and reaches about $50 \%$. Similar pattern was repeated during evening cooking hours. Only during these two cooking periods, fossil fuel fraction BC was lower. Otherwise it remained significantly higher than biomass burning $\mathrm{BC}$ throughout the day. On average, $\sim 40 \%$ of $\mathrm{BC}$ was from biomass burning whereas the remaining $60 \%$ was contributed by fossil fuel combustion during our measurement period. Interestingly, this is the opposite of the contributions that were concluded by Lawrence and Lelieveld (2010). Lawrence and Lelieveld (2010) concluded that $\sim 60 \%$ BC came from biomass vs. $\sim 40 \%$ from fossil fuel, based on a review of numerous previous studies to be likely for studies on the outflows from South Asia during the winter monsoon. When we compared observed AAE with Praveen et al. (2012), we noticed that

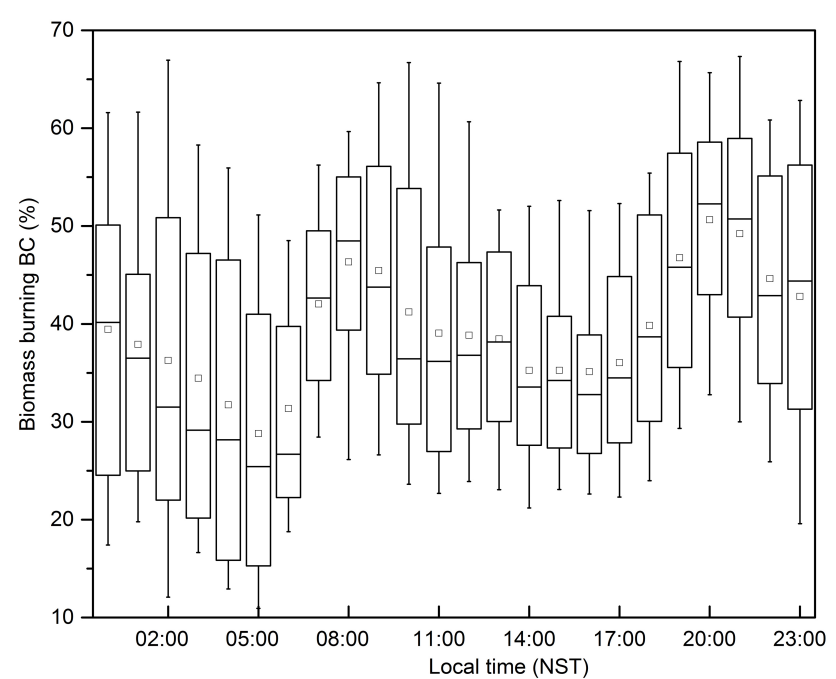

Figure 12. Diurnal variation of the fractional contribution of biomass burning to ambient $\mathrm{BC}$ concentration at Lumbini for the measurement period. In each box, the lower and upper boundary of the box represent the 25th and 75th percentile, respectively, and the top and bottom of the whisker represent the 90th and 10th percentile, respectively. The mid-line in each box represents the median while the square mark represents the mean for each hour.

Lumbini values were lower than the Project Surya village site. This implies that Surya village center had a higher biomass fraction; additionally, it was observed absorption AAE exceeded 1.86 during cooking hours, which indicates $100 \%$ biomass contribution. The difference is attributed to the fact that Lumbini sampling site is not a residential site like Surya, which can capture cooking influence efficiently. Further Lumbini sampling site is surrounded by commercial activities such as a local bus park, hotels, office buildings and industries and brick kilns slightly further away. Although the reason for this difference is not clear, it is an indication of the important role of diesel and coal emissions in the Lumbini and upwind regions.

\section{Conclusions}

Our measurements, a first for the Lumbini area, have shown very high air pollution at Lumbini. $\mathrm{BC}, \mathrm{CO}, \mathrm{O}_{3}$ and particulate matter $\left(\mathrm{PM}_{10}, \mathrm{PM}_{2.5}\right.$ and $\left.\mathrm{PM}_{1}\right)$ were measured during the pre-monsoon of 2013 at a regional site of the SusKatABC campaign. Average pollutant concentrations during the monitoring period were found to be $4.9 \pm 3.8 \mu \mathrm{g} \mathrm{m}^{-3}$ for $\mathrm{BC}, 344.1 \pm 160.3 \mathrm{ppbv}$ for $\mathrm{CO}, 46.6 \pm 20.3 \mathrm{ppbv}$ for $\mathrm{O}_{3}$, $128.8 \pm 91.9 \mu \mathrm{g} \mathrm{m}^{-3}$ for $\mathrm{PM}_{10}, 53.14 \pm 35.1 \mu \mathrm{g} \mathrm{m}^{-3}$ for $\mathrm{PM}_{2.5}$ and $36.6 \pm 25.7 \mu \mathrm{g} \mathrm{m}^{-3}$ for $\mathrm{PM}_{1}$, which is comparable with other urban sites like Kanpur and Delhi in the IGP region. However, our study finds a higher fraction of coarse-mode PM in Lumbini compared to other sites in the IGP region. In addition, the $\triangle \mathrm{BC} / \triangle \mathrm{CO}$ ratio obtained in Lumbini was 
within the range of emissions from both residential and transportation sectors, indicating them as potential key sources of $\mathrm{BC}$ and $\mathrm{CO}$ and likely most of $\mathrm{PM}_{1}$ in Lumbini. The diurnal variation of the pollutants is similar to that of any urban location, with peaks during morning and evening. However, our results show higher evening concentration compared to morning concentration values, further research is needed to explain this behavior. During our measurement period, air quality in Lumbini was influenced by regional forest fires as shown by chemical transport model and satellite data analysis. A regional chemical transport model, WRFSTEM, was used to understand observations. Intercomparison of WRF-STEM model outputs with observations showed that the model underestimated the observed pollutant concentrations by a factor of $\sim 1.5$ to 5 but was able to capture the temporal variability. Model uncertainties are attributed mostly to uncertainties in meteorology and regional emissions as shown from sensitivity analysis with local emissions. Regionally tagged $\mathrm{CO}$ as air-mass tracers is employed in WRF-STEM model to understand the anthropogenic emission source region influencing Lumbini. Our analysis shows that the adjacent regions, mostly the Ganges Valley, other parts of India and Nepal, accounted for the highest contribution to pollutant concentration in the Lumbini. The normalized light absorption curve clearly indicated the contribution to BC in Lumbini from both sources: biomass as well as fossil fuel. On average, $\sim 40 \% \mathrm{BC}$ was found to be from the biomass burning and $\sim 60 \%$ from fossil fuel burning.

Various improvements and extensions are possible in future studies. More reliable functioning of the AWS (temperature and RH sensor, rain gauge) would have allowed more in-depth analysis of the relationship between meteorological parameters and pollutants concentration. Continuous measurements of air pollutants throughout the year would allow for annual and seasonal variation study. Improvements in the model performance are much needed in its ability to simulate observed meteorology. Significant uncertainty lies with the regional emission inventory developed at national and continental scale vs. local bottom-up inventory and pollutant emissions from small-scale open burning not captured by satellites. There is a clear need to set up a continuous air quality monitoring station at Lumbini and the surrounding regions for long-term air quality monitoring.

Data availability. The observation data used for this paper can be obtained by sending an email to the corresponding authors and/or to IASS (maheswar.rupakheti@iass.potsdam.de) and/or to ICIMOD (arnico.panday@icimod.org). Modeling data can be obtained from Bhupesh Adhikary (bhupesh.adhikary@icimod.org).

The Supplement related to this article is available online at https://doi.org/10.5194/acp-17-11041-2017supplement.
Author contributions. MR and ML conceived the Lumbini portion of the SusKat experiment. MR and AKP coordinated the Lumbini field campaign. DR and KSM conducted the field observations at Lumbini. BA designed and ran the WRF-STEM model. PSP, BA and DR finalized the manuscript composition. DR, PSP, BA, MR and SK conducted the data analysis. DR and BA prepared the manuscript with inputs from all coauthors.

Competing interests. The authors declare that they have no conflict of interest.

Special issue statement. This article is part of the special issue "Atmospheric pollution in the Himalayan foothills: The SusKat-ABC international air pollution measurement campaign". It is not associated with a conference.

Acknowledgements. This study was partly supported by the Institute for Advanced Sustainability Studies (IASS), Germany, the International Centre for Integrated Mountain Development (ICIMOD), the National Natural Science Foundation of China $(41630754,41421061)$ and the State Key Laboratory of Cryospheric Science (SKLCS-ZZ-2016). Dipesh Rupakheti is supported by CAS-TWAS President's Fellowship for International $\mathrm{PhD}$ Students. The IASS is grateful for its funding from the German Federal Ministry for Education and Research (BMBF) and the Brandenburg Ministry for Science, Research and Culture (MWFK). ICIMOD authors would like to acknowledge that this study was partially supported by core funds of ICIMOD contributed by the governments of Afghanistan, Australia, Austria, Bangladesh, Bhutan, China, India, Myanmar, Nepal, Norway, Pakistan, Switzerland and the UK. The views and interpretations in this publication are those of the authors and are not necessarily attributable to the institutions they are associated with. We thank Bhogendra Kathayat, Bhoj Raj Bhatta, and Venerable Vivekananda and his colleagues (Panditarama Lumbini International Vipassana Meditation Center) for providing logistical support which was vital in setting up and running the site. We also thank Christoph Cüppers and Michael Pahlke of the Lumbini International Research Institute (LIRI) for proving the space and power to run the instruments at the LIRI premises. Satellite data providers (MODIS, AIRS, OMI) and HYSPLIT team are also equally acknowledged.

Edited by: Kim Oanh Nguyen Thi

Reviewed by: four anonymous referees

\section{References}

Adhikary, B., Carmichael, G. R., Tang, Y., Leung, L. R., Qian, Y., Schauer, J. J., Stone, E. A., Ramanathan, V., and Ramana, M. V.: Characterization of the seasonal cycle of south Asian aerosols: a regional-scale modeling analysis, J. Geophys. Res., 112, 1-22, https://doi.org/10.1029/2006jd008143, 2007.

Adhikary, B., Carmichael, G. R., Kulkarni, S., Wei, C., Tang, Y., D’Allura, A., Mena-Carrasco, M., Streets, D. G., Zhang, Q., Pierce, R. B., Al-Saadi, J. A., Emmons, L. K., Pfister, G. G., 
Avery, M. A., Barrick, J. D., Blake, D. R., Brune, W. H., Cohen, R. C., Dibb, J. E., Fried, A., Heikes, B. G., Huey, L. G., O’Sullivan, D. W., Sachse, G. W., Shetter, R. E., Singh, H. B., Campos, T. L., Cantrell, C. A., Flocke, F. M., Dunlea, E. J., Jimenez, J. L., Weinheimer, A. J., Crounse, J. D., Wennberg, P. O., Schauer, J. J., Stone, E. A., Jaffe, D. A., and Reidmiller, D. R.: A regional scale modeling analysis of aerosol and trace gas distributions over the eastern Pacific during the INTEX-B field campaign, Atmos. Chem. Phys., 10, 2091-2115, https://doi.org/10.5194/acp-10-2091-2010, 2010.

Andreae, M. O. and Gelencsér, A.: Black carbon or brown carbon? The nature of light-absorbing carbonaceous aerosols, Atmos. Chem. Phys., 6, 3131-3148, https://doi.org/10.5194/acp-63131-2006, 2006.

Antony Chen, L. W., Doddridge, B. G., Dickerson, R. R., Chow, J. C., Mueller, P. K., Quinn, J., and Butler, W. A.: Seasonal variations in elemental carbon aerosol, carbon monoxide and sulfur dioxide: Implications for sources, Geophys. Res. Lett., 28, 17111714, https://doi.org/10.1029/2000g1012354, 2001.

Badarinath, K. V. S., Latha, K. M., Chand, T. R. K., Reddy, R. R., Gopal, K. R., Reddy, L. S. S., Narasimhulu, K., and Kumar, K. R.: Black carbon aerosols and gaseous pollutants in an urban area in North India during a fog period, Atmos. Res., 85, 209-216, https://doi.org/10.1016/j.atmosres.2006.12.007, 2007.

Bergin, M. H., Tripathi, S. N., Jai Devi, J., Gupta, T., McKenzie, M., Rana, K., Shafer, M. M., Villalobos, A. M., and Schauer, J. J.: The discoloration of the Taj Mahal due to particulate carbon and dust deposition, Environ. Sci. Technol., 49, 808-812, https://doi.org/10.1021/es504005q, 2015.

Bergstrom, R. W., Pilewskie, P., Russell, P., Redemann, J., Bond, T., Quinn, P., and Sierau, B.: Spectral absorption properties of atmospheric aerosols, Atmos. Chem. Phys., 7, 5937-5943, https://doi.org/10.5194/acp-7-5937-2007, 2007.

Bisht, D. S., Dumka, U. C., Kaskaoutis, D. G., Pipal, A. S., Srivastava, A. K., Soni, V. K., Attri, S. D., Sateesh, M., and Tiwari, S.: Carbonaceous aerosols and pollutants over Delhi urban environment: temporal evolution, source apportionment and radiative forcing, Sci. Total Environ., 521, 431-445, https://doi.org/10.1016/j.scitotenv.2015.03.083, 2015.

Bonasoni, P., Laj, P., Marinoni, A., Sprenger, M., Angelini, F., Arduini, J., Bonafè, U., Calzolari, F., Colombo, T., Decesari, S., Di Biagio, C., di Sarra, A. G., Evangelisti, F., Duchi, R., Facchini, M. C., Fuzzi, S., Gobbi, G. P., Maione, M., Panday, A., Roccato, F., Sellegri, K., Venzac, H., Verza, G. P., Villani, P., Vuillermoz, E., and Cristofanelli, P.: Atmospheric Brown Clouds in the Himalayas: first two years of continuous observations at the Nepal Climate Observatory-Pyramid (5079 m), Atmos. Chem. Phys., 10, 7515-7531, https://doi.org/10.5194/acp-107515-2010, 2010.

Brimblecombe, P.: The effects of air pollution on the built environment, Imperial College Press, London, 2003.

Burney, J. and Ramanathan, V.: Recent climate and air pollution impacts on Indian agriculture, P. Natl. Acad. Sci. USA, 111, 1631916324, https://doi.org/10.1073/pnas.1317275111, 2014.

Cao, J.-J., Zhu, C.-S., Chow, J. C., Watson, J. G., Han, Y.-M., Wang, G.-H., Shen, Z.-X., and An, Z.-S.: Black carbon relationships with emissions and meteorology in Xi'an, China, Atmos. Res., 94, 194-202, https://doi.org/10.1016/j.atmosres.2009.05.009, 2009.
Cong, Z., Kang, S., Kawamura, K., Liu, B., Wan, X., Wang, Z., Gao, S., and Fu, P.: Carbonaceous aerosols on the south edge of the Tibetan Plateau: concentrations, seasonality and sources, Atmos. Chem. Phys., 15, 1573-1584, https://doi.org/10.5194/acp15-1573-2015, 2015a.

Cong, Z., Kawamura, K., Kang, S., and Fu, P.: Penetration of biomass-burning emissions from South Asia through the Himalayas: new insights from atmospheric organic acids, Sci. Rep.UK, 5, 1-7, https://doi.org/10.1038/srep09580, 2015 b.

Cristofanelli, P., Bracci, A., Sprenger, M., Marinoni, A., Bonafè, U., Calzolari, F., Duchi, R., Laj, P., Pichon, J. M., Roccato, F., Venzac, H., Vuillermoz, E., and Bonasoni, P.: Tropospheric ozone variations at the Nepal Climate ObservatoryPyramid (Himalayas, 5079 ma.s.1.) and influence of deep stratospheric intrusion events, Atmos. Chem. Phys., 10, 6537-6549, https://doi.org/10.5194/acp-10-6537-2010, 2010.

Cristofanelli, P., Fierli, F., Marinoni, A., Calzolari, F., Duchi, R., Burkhart, J., Stohl, A., Maione, M., Arduini, J., and Bonasoni, P.: Influence of biomass burning and anthropogenic emissions on ozone, carbon monoxide and black carbon at the Mt. Cimone GAW-WMO global station (Italy, $2165 \mathrm{~m}$ a.s.l.), Atmos. Chem. Phys., 13, 15-30, https://doi.org/10.5194/acp-13-15-2013, 2013.

Das, S. K. and Jayaraman, A.: Role of black carbon in aerosol properties and radiative forcing over western India during premonsoon period, Atmos. Res., 102, 320-334, https://doi.org/10.1016/j.atmosres.2011.08.003, 2011.

Day, D., Hand, J., Carrico, C., Engling, G., and Malm, W.: Humidification factors from laboratory studies of fresh smoke from biomass fuels, J. Geophys. Res., 111, D22202, https://doi.org/10.1029/2006JD007221, 2006.

Dickerson, R. R., Andreae, M. O., Campos, T., MayolBracero, O. L., Neusuess, C., and Streets, D. G.: Analysis of black carbon and carbon monoxide observed over the Indian Ocean: implications for emissions and photochemistry, J. Geophys. Res.-Atmos., 107, 8017, https://doi.org/10.1029/2001JD000501, 2002.

Duchi, R., Cristofanelli, P., Marinoni, A., Laj, P., Marcq, S., Villani, P., Sellegri, K., Angelini, F., Calzolari, F., Gobbi, G. P., Verza, G. P., Vuillermoz, E., Sapkota, A., and Bonasoni, P.: Continuous observations of synoptic-scale dust transport at the Nepal Climate Observatory-Pyramid (5079 ma.s.1.) in the Himalayas, Atmos. Chem. Phys. Discuss., 11, 4229-4261, https://doi.org/10.5194/acpd-11-4229-2011, 2011.

Forouzanfar, M. H., Alexander, L., Anderson, H. R., Bachman, V. F., Biryukov, S., Brauer, M., Burnett, R., Casey, D., Coates, M. M., and Cohen, A.: Global, regional, and national comparative risk assessment of 79 behavioural, environmental and occupational, and metabolic risks or clusters of risks in 188 countries, 1990-2013: a systematic analysis for the Global Burden of Disease Study 2013, Lancet, 386, 2287-2323, https://doi.org/10.1016/S0140-6736(15)00128-2, 2015.

Ganguly, D., Jayaraman, A., Rajesh, T. A., and Gadhavi, H.: Wintertime aerosol properties during foggy and nonfoggy days over urban center Delhi and their implications for shortwave radiative forcing, J. Geophys. Res., 111, 1-15, https://doi.org/10.1029/2005jd007029, 2006.

Gaur, A., Tripathi, S. N., Kanawade, V. P., Tare, V., and Shukla, S. P.: Four-year measurements of trace gases $\left(\mathrm{SO}_{2}, \mathrm{NO}_{x}\right.$, $\mathrm{CO}$, and $\mathrm{O}_{3}$ ) at an urban location, Kanpur, in Northern India, 
J. Atmos. Chem., 71, 283-301, https://doi.org/10.1007/s10874014-9295-8, 2014.

Gauri, K. L. and Holdren, G.: Pollutant effects on stone monuments, Environ. Sci. Technol., 15, 386-390, https://doi.org/10.1021/es00086a001, 1981.

Girach, I. A., Nair, V. S., Babu, S. S., and Nair, P. R.: Black carbon and carbon monoxide over Bay of Bengal during W_ICARB: source characteristics, Atmos. Environ., 94, 508517, https://doi.org/10.1016/j.atmosenv.2014.05.054, 2014.

Hobbs, P. V., Sinha, P., Yokelson, R. J., Christian, T. J., Blake, D. R., Gao, S., Kirchstetter, T. W., Novakov, T., and Pilewskie, P.: Evolution of gases and particles from a savanna fire in South Africa, J. Geophys. Res., 108, 8485, https://doi.org/10.1029/2002JD002352, 2003.

Huang, X.-F., Sun, T.-L., Zeng, L.-W., Yu, G.-H., and Luan, S.-J.: Black carbon aerosol characterization in a coastal city in South China using a single particle soot photometer, Atmos. Environ., 51, 21-28, https://doi.org/10.1016/j.atmosenv.2012.01.056, 2012.

IPCC: Climate Change 2013: The physical science basis, in: Contribution of Working Group I to the Fifth Assessment Report of the Intergovernmental Panel on Climate Change, edited by: Stocker, T. F., Qin, D., Plattner, G.-K., Tignor, M., Allen, S. K., Boschung, J., Nauels, A., Xia, Y., Bex, V., and Midgley, P. M., Cambridge University Press, Cambridge, UK and New York, NY, USA, 1535 pp., 2013.

Jaffe, D., Mahura, A., Kelley, J., Atkins, J., Novelli, P. C., and Merrill, J.: Impact of Asian emissions on the remote North Pacific atmosphere: interpretation of $\mathrm{CO}$ data from Shemya, Guam, Midway and Mauna Loa, J. Geophys. Res., 102, 28627, https://doi.org/10.1029/96jd02750, 1997.

Joshi, H., Naja, M., Singh, K., Kumar, R., Bhardwaj, P., Babu, S. S., Satheesh, S., Moorthy, K. K., and Chandola, H.: Investigations of aerosol black carbon from a semi-urban site in the Indo-Gangetic Plain region, Atmos. Environ., 125, 346-359, https://doi.org/10.1016/j.atmosenv.2015.04.007, 2016.

Kirchstetter, T. W., Novakov, T., and Hobbs, P. V.: Evidence that the spectral dependence of light absorption by aerosols is affected by organic carbon, J. Geophys. Res., 109, 1-12, https://doi.org/10.1029/2004JD004999, 2004.

Kondo, Y., Matsui, H., Moteki, N., Sahu, L., Takegawa, N., Kajino, M., Zhao, Y., Cubison, M. J., Jimenez, J. L., Vay, S., Diskin, G. S., Anderson, B., Wisthaler, A., Mikoviny, T., Fuelberg, H. E., Blake, D. R., Huey, G., Weinheimer, A. J., Knapp, D. J., and Brune, W. H.: Emissions of black carbon, organic, and inorganic aerosols from biomass burning in North America and Asia in 2008, J. Geophys. Res., 116, D08204, https://doi.org/10.1029/2010JD015152, 2011.

Kulkarni, S., Sobhani, N., Miller-Schulze, J. P., Shafer, M. M., Schauer, J. J., Solomon, P. A., Saide, P. E., Spak, S. N., Cheng, Y. F., Denier van der Gon, H. A. C., Lu, Z., Streets, D. G., Janssens-Maenhout, G., Wiedinmyer, C., Lantz, J., Artamonova, M., Chen, B., Imashev, S., Sverdlik, L., Deminter, J. T., Adhikary, B., D'Allura, A., Wei, C., and Carmichael, G. R.: Source sector and region contributions to BC and $\mathrm{PM}_{2.5}$ in Central Asia, Atmos. Chem. Phys., 15, 1683-1705, https://doi.org/10.5194/acp-15-1683-2015, 2015.

Kumar, B., Chakraborty, A., Tripathi, S. N., and Bhattu, D.: Highly time resolved chemical characterization of submicron organic aerosols at a polluted urban location, Environ. Sci.-Proc. Imp. 18, 1285-1296, https://doi.org/10.1039/C6EM00392C, 2016a.

Kumar, M., Tiwari, S., Murari, V., Singh, A. K., and Banerjee, T.: Wintertime characteristics of aerosols at middle Indo-Gangetic Plain: impacts of regional meteorology and long range transport, Atmos. Environ., 104, 162-175, https://doi.org/10.1016/j.atmosenv.2015.01.014, 2015.

Kumar, V., Sarkar, C., and Sinha, V.: Influence of post harvest crop residue fires on surface ozone mixing ratios in the NW IGP analyzed using two years of continuous in-situ trace gas measurements, J. Geophys. Res.-Atmos., 121, 3619-3633, https://doi.org/10.1002/2015JD024308, 2016 b.

Latha, K. M. and Badarinath, K. V. S.: Correlation between black carbon aerosols, carbon monoxide and tropospheric ozone over a tropical urban site, Atmos. Res., 71, 265-274, https://doi.org/10.1016/j.atmosres.2004.06.004, 2004.

Lawrence, M. G. and Lelieveld, J.: Atmospheric pollutant outflow from southern Asia: a review, Atmos. Chem. Phys., 10, 11017 11096, https://doi.org/10.5194/acp-10-11017-2010, 2010.

Lüthi, Z. L., Škerlak, B., Kim, S. W., Lauer, A., Mues, A., Rupakheti, M., and Kang, S.: Atmospheric brown clouds reach the Tibetan Plateau by crossing the Himalayas, Atmos. Chem. Phys., 15, 6007-6021, https://doi.org/10.5194/acp-156007-2015, 2015.

Marinoni, A., Cristofanelli, P., Laj, P., Duchi, R., Putero, D., Calzolari, F., Landi, T. C., Vuillermoz, E., Maione, M., and Bonasoni, P.: High black carbon and ozone concentrations during pollution transport in the Himalayas: five years of continuous observations at NCO-P global GAW station, J. Environ. Sci., 25, 1618-1625, https://doi.org/10.1016/s1001-0742(12)602423, 2013.

Misra, A., Gaur, A., Bhattu, D., Ghosh, S., Dwivedi, A. K., Dalai, R., Paul, D., Gupta, T., Tare, V., Mishra, S. K., Singh, S., and Tripathi, S. N.: An overview of the physicochemical characteristics of dust at Kanpur in the central Indo-Gangetic basin, Atmos. Environ., 97, 386-396, https://doi.org/10.1016/j.atmosenv.2014.08.043, 2014.

Mohnen, V. A., Goldstein, W., and Wang, W. C.: Tropospheric Ozone and Climate Change, Air and Waste, 43, 1332-1334, https://doi.org/10.1080/1073161x.1993.10467207, 1993.

Naja, M., Lal, S., and Chand, D.: Diurnal and seasonal variabilities in surface ozone at a high altitude site $\mathrm{Mt} \mathrm{Abu}\left(24.6^{\circ} \mathrm{N}\right.$, $72.7^{\circ}$ E, 1680 ma.s.1.) in India, Atmos. Environ., 37, 4205-4215, https://doi.org/10.1016/S1352-2310(03)00565-X, 2003.

Pan, X. L., Kanaya, Y., Wang, Z. F., Liu, Y., Pochanart, P., Akimoto, H., Sun, Y. L., Dong, H. B., Li, J., Irie, H., and Takigawa, M.: Correlation of black carbon aerosol and carbon monoxide in the high-altitude environment of Mt. Huang in Eastern China, Atmos. Chem. Phys., 11, 9735-9747, https://doi.org/10.5194/acp-11-9735-2011, 2011.

Panday, A. K. and Prinn, R. G.: Diurnal cycle of air pollution in the Kathmandu Valley, Nepal: observations, J. Geophys. Res., 114, 1-19, https://doi.org/10.1029/2008jd009777, 2009.

Park, S. S., Harrison, D., Pancras, J. P., and Ondov, J. M.: Highly time-resolved organic and elemental carbon measurements at the Baltimore Supersite in 2002, J. Geophys. Res., 110, D07S06, https://doi.org/10.1029/2004jd004610, 2005.

Pathak, B., Bhuyan, P. K., Biswas, J., and Takemura, T.: Long term climatology of particulate matter and as- 
sociated microphysical and optical properties over Dibrugarh, North-East India and inter-comparison with SPRINTARS simulations, Atmos. Environ., 69, 334-344, https://doi.org/10.1016/j.atmosenv.2012.12.032, 2013.

Praveen, P. S., Ahmed, T., Kar, A., Rehman, I. H., and Ramanathan, V.: Link between local scale BC emissions in the Indo-Gangetic Plains and large scale atmospheric solar absorption, Atmos. Chem. Phys., 12, 1173-1187, https://doi.org/10.5194/acp-12-1173-2012, 2012.

Putero, D., Landi, T., Cristofanelli, P., Marinoni, A., Laj, P., Duchi, R., Calzolari, F., Verza, G., and Bonasoni, P.: Influence of open vegetation fires on black carbon and ozone variability in the southern Himalayas (NCO-P, 5079 ma.s.1.), Environ. Pollut., 184, 597-604, https://doi.org/10.1016/j.envpol.2013.09.035, 2014.

Putero, D., Cristofanelli, P., Marinoni, A., Adhikary, B., Duchi, R., Shrestha, S. D., Verza, G. P., Landi, T. C., Calzolari, F., Busetto, M., Agrillo, G., Biancofiore, F., Di Carlo, P., Panday, A. K., Rupakheti, M., and Bonasoni, P.: Seasonal variation of ozone and black carbon observed at Paknajol, an urban site in the Kathmandu Valley, Nepal, Atmos. Chem. Phys., 15, 1395713971, https://doi.org/10.5194/acp-15-13957-2015, 2015.

Ram, K., Sarin, M., and Tripathi, S.: A 1 year record of carbonaceous aerosols from an urban site in the Indo-Gangetic Plain: characterization, sources, and temporal variability, J. Geophys. Res., 115, D24313, https://doi.org/10.1029/2010JD014188, 2010.

Ramachandran, S. and Rajesh, T. A.: Black carbon aerosol mass concentrations over Ahmedabad, an urban location in western India: comparison with urban sites in Asia, Europe, Canada, and the United States, J. Geophys. Res., 112, 1-19, https://doi.org/10.1029/2006JD007488, 2007.

Ramanathan, V. and Carmichael, G.: Global and regional climate changes due to black carbon, Nat. Geosci., 1, 221-227, 2008.

Ramanathan, V., Li, F., Ramana, M., Praveen, P., Kim, D., Corrigan, C., Nguyen, H., Stone, E. A., Schauer, J. J., and Carmichael, G.: Atmospheric brown clouds: hemispherical and regional variations in long-range transport, absorption, and radiative forcing, J. Geophys. Res., 112, 1-26, https://doi.org/10.1029/2006JD008124, 2007.

Rastogi, N., Singh, A., Sarin, M. M., and Singh, D.: Temporal variability of primary and secondary aerosols over northern India: impact of biomass burning emissions, Atmos. Environ., 125, 396-403, https://doi.org/10.1016/j.atmosenv.2015.06.010, 2016.

Rehman, I. H., Ahmed, T., Praveen, P. S., Kar, A., and Ramanathan, V.: Black carbon emissions from biomass and fossil fuels in rural India, Atmos. Chem. Phys., 11, 7289-7299, https://doi.org/10.5194/acp-11-7289-2011, 2011.

Retama, A., Baumgardner, D., Raga, G. B., McMeeking, G. R., and Walker, J. W.: Seasonal and diurnal trends in black carbon properties and co-pollutants in Mexico City, Atmos. Chem. Phys., 15, 9693-9709, https://doi.org/10.5194/acp-15-9693-2015, 2015.

Rupakheti, M., Panday, A. K., Lawrence, M. G., Kim, S. W., Sinha, V., Kang, S. C., Naja, M., Park, J. S., Hoor, P., Holben, B., Sharma, R. K., Mues, A., Mahata, K. S., Bhardwaj, P., Sarkar, C., Rupakheti, D., Regmi, R. P., and Gustafsson, Ö.: Air pollution in the Himalayan foothills: overview of the SusKat-ABC international air pollution measurement campaign in Nepal, Atmos. Chem. Phys. Discuss., in preparation, 2017.
Safai, P. D., Kewat, S., Pandithurai, G., Praveen, P. S., Ali, K., Tiwari, S., Rao, P. S. P., Budhawant, K. B., Saha, S. K., and Devara, P. C. S.: Aerosol characteristics during winter fog at Agra, North India, J. Atmos. Chem., 61, 101-118, https://doi.org/10.1007/s10874-009-9127-4, 2009.

Sahu, L. K., Kondo, Y., Moteki, N., Takegawa, N., Zhao, Y., Cubison, M. J., Jimenez, J. L., Vay, S., Diskin, G. S., Wisthaler, A., Mikoviny, T., Huey, L. G., Weinheimer, A. J., and Knapp, D. J.: Emission characteristics of black carbon in anthropogenic and biomass burning plumes over California during ARCTAS-CARB 2008, J. Geophys. Res., 117, D16302, https://doi.org/10.1029/2011jd017401, 2012.

Sandradewi, J., Prévôt, A. S. H., Szidat, S., Perron, N., Alfarra, M. R., Lanz, V. A., Weingartner, E., and Baltensperger, U.: Using aerosol light absorption measurements for the quantitative determination of wood burning and traffic emission contributions to particulate matter, Environ. Sci. Technol., 42, 33163323, https://doi.org/10.1021/es702253m, 2008.

Sarkar, C., Kumar, V., and Sinha, V.: Massive emissions of carcinogenic benzenoids from paddy residue burning in north India, Curr. Sci. India, 104, 1703-1709, 2013.

Schmid, O., Artaxo, P., Arnott, W. P., Chand, D., Gatti, L. V., Frank, G. P., Hoffer, A., Schnaiter, M., and Andreae, M. O.: Spectral light absorption by ambient aerosols influenced by biomass burning in the Amazon Basin. I: Comparison and field calibration of absorption measurement techniques, Atmos. Chem. Phys., 6, 3443-3462, https://doi.org/10.5194/acp-6-34432006, 2006.

Sharma, R. K., Bhattarai, B. K., Sapkota, B. K., Gewali, M. B., and Kjeldstad, B.: Black carbon aerosols variation in Kathmandu valley, Nepal, Atmos. Environ., 63, 282-288, https://doi.org/10.1016/j.atmosenv.2012.09.023, 2012.

Sharma, S., Brook, J. R., Cachier, H., Chow, J., Gaudenzi, A., and Lu, G.: Light absorption and thermal measurements of black carbon in different regions of Canada, J. Geophys. Res.-Atmos., 107, 1-11, https://doi.org/10.1029/2002JD002496, 2002.

Shindell, D., Kuylenstierna, J. C., Vignati, E., van Dingenen, R., Amann, M., Klimont, Z., Anenberg, S. C., Muller, N., JanssensMaenhout, G., and Raes, F.: Simultaneously mitigating near-term climate change and improving human health and food security, Science, 335, 183-189, 2012.

Singh, N., Murari, V., Kumar, M., Barman, S. C., and Banerjee, T.: Fine particulates over South Asia: review and meta-analysis of $\mathrm{PM}_{2.5}$ source apportionment through receptor model, Environ. Pollut., 223, 121-136, https://doi.org/10.1016/j.envpol.2016.12.071, 2017.

Sinha, V., Kumar, V., and Sarkar, C.: Chemical composition of premonsoon air in the Indo-Gangetic Plain measured using a new air quality facility and PTR-MS: high surface ozone and strong influence of biomass burning, Atmos. Chem. Phys., 14, 59215941, https://doi.org/10.5194/acp-14-5921-2014, 2014.

Skamarock, W., Klemp, J., Dudhia, J., Gill, D., and Barker, D.: A description of the Advanced Research WRF version 3, Technical Report NCAR/TN475 + STR, National Center for Atmospheric Research Technical Note, Boulder, Colorado, 2008.

Snider, G., Weagle, C. L., Murdymootoo, K. K., Ring, A., Ritchie, Y., Stone, E., Walsh, A., Akoshile, C., Anh, N. X., Balasubramanian, R., Brook, J., Qonitan, F. D., Dong, J., Griffith, D., He, K., Holben, B. N., Kahn, R., Lagrosas, N., Lestari, P., Ma, Z., 
Misra, A., Norford, L. K., Quel, E. J., Salam, A., Schichtel, B., Segev, L., Tripathi, S., Wang, C., Yu, C., Zhang, Q., Zhang, Y., Brauer, M., Cohen, A., Gibson, M. D., Liu, Y., Martins, J. V., Rudich, Y., and Martin, R. V.: Variation in global chemical composition of $\mathrm{PM}_{2.5}$ : emerging results from SPARTAN, Atmos. Chem. Phys., 16, 9629-9653, https://doi.org/10.5194/acp16-9629-2016, 2016.

Stevenson, D., Dentener, F., Schultz, M., Ellingsen, K., Van Noije, T., Wild, O., Zeng, G., Amann, M., Atherton, C., and Bell, N.: Multimodel ensemble simulations of present-day and near-future tropospheric ozone, J. Geophys. Res., 111, 1-23, https://doi.org/10.1029/2005JD006338, 2006.

Subramanian, R., Kok, G. L., Baumgardner, D., Clarke, A., Shinozuka, Y., Campos, T. L., Heizer, C. G., Stephens, B. B., de Foy, B., Voss, P. B., and Zaveri, R. A.: Black carbon over Mexico: the effect of atmospheric transport on mixing state, mass absorption cross-section, and BC / CO ratios, Atmos. Chem. Phys., 10, 219-237, https://doi.org/10.5194/acp-10-219-2010, 2010.

Tiwari, S., Srivastava, A. K., Bisht, D. S., Parmita, P., Srivastava, M. K., and Attri, S. D.: Diurnal and seasonal variations of black carbon and $\mathrm{PM}_{2.5}$ over New Delhi, India: influence of meteorology, Atmos. Res., 125, 50-62, https://doi.org/10.1016/j.atmosres.2013.01.011, 2013.

Tiwari, S., Pipal, A. S., Hopke, P. K., Bisht, D. S., Srivastava, A. K., Tiwari, S., Saxena, P. N., Khan, A. H., and Pervez, S.: Study of the carbonaceous aerosol and morphological analysis of fine particles along with their mixing state in Delhi, India: a case study, Environ. Sci. Pollut. R., 22, 10744-10757, https://doi.org/10.1007/s11356-015-4272-6, 2015.

Tiwari, S., Dumka, U. C., Kaskaoutis, D. G., Ram, K., Panicker, A. S., Srivastava, M. K., Tiwari, S., Attri, S. D., Soni, V. K., and Pandey, A. K.: Aerosol chemical characterization and role of carbonaceous aerosol on radiative effect over Varanasi in central Indo-Gangetic Plain, Atmos. Environ., 125, 437-449, https://doi.org/10.1016/j.atmosenv.2015.07.031, 2016.

Tiwari, S., Dumka, U. C., Gautam, A. S., Kaskaoutis, D. G., Srivastava, A. K., Bisht, D. S., Chakrabarty, R. K., Sumlin, B. J., and Solmon, F.: Assessment of $\mathrm{PM}_{2.5}$ and $\mathrm{PM}_{10}$ over Guwahati in Brahmaputra River Valley: temporal evolution, source apportionment and meteorological dependence, Atmos. Pollut. Res., 8, 13-28, https://doi.org/10.1016/j.apr.2016.07.008, 2017.

Val Martín, M., Honrath, R. E., Owen, R. C., Pfister, G., Fialho, P., and Barata, F.: Significant enhancements of nitrogen oxides, black carbon, and ozone in the North Atlantic lower free troposphere resulting from North American boreal wildfires, J. Geophys. Res., 111, D23S60, https://doi.org/10.1029/2006jd007530, 2006.
Verma, R. L., Sahu, L. K., Kondo, Y., Takegawa, N., Han, S., Jung, J. S., Kim, Y. J., Fan, S., Sugimoto, N., Shammaa, M. H., Zhang, Y. H., and Zhao, Y.: Temporal variations of black carbon in Guangzhou, China, in summer 2006, Atmos. Chem. Phys., 10, 6471-6485, https://doi.org/10.5194/acp-10-6471-2010, 2010.

Verma, R. L., Kondo, Y., Oshima, N., Matsui, H., Kita, K., Sahu, L. K., Kato, S., Kajii, Y., Takami, A., and Miyakawa, T. Seasonal variations of the transport of black carbon and carbon monoxide from the Asian continent to the western Pacific in the boundary layer, J. Geophys. Res., 116, D21307, https://doi.org/10.1029/2011jd015830, 2011.

Verma, S., Worden, J., Payra, S., Jourdain, L., and Shim, C.: Characterizing the long-range transport of black carbon aerosols during Transport and Chemical Evolution over the Pacific (TRACE-P) experiment, Environ. Monit. Assess., 154, 85-92, https://doi.org/10.1007/s10661-008-0379-2, 2009.

Wan, X., Kang, S., Li, Q., Rupakheti, D., Zhang, Q., Guo, J., Chen, P., Tripathee, L., Rupakheti, M., Panday, A. K., Wang, W., Kawamura, K., Gao, S., Wu, G., and Cong, Z.: Organic molecular tracers in the atmospheric aerosols from Lumbini, Nepal, in the northern Indo-Gangetic Plain: influence of biomass burning, Atmos. Chem. Phys., 17, 8867-8885, https://doi.org/10.5194/acp-17-8867-2017, 2017.

WHO: Air quality guidelines: global update 2005: particulate matter, ozone, nitrogen dioxide, and sulfur dioxide, World Health Organization, Geneva, 22 pp., 2006.

Wiedinmyer, C., Akagi, S. K., Yokelson, R. J., Emmons, L. K., AlSaadi, J. A., Orlando, J. J., and Soja, A. J.: The Fire INventory from NCAR (FINN): a high resolution global model to estimate the emissions from open burning, Geosci. Model Dev., 4, 625641, https://doi.org/10.5194/gmd-4-625-2011, 2011.

Zhou, X., Gao, J., Wang, T., Wu, W., and Wang, W.: Measurement of black carbon aerosols near two Chinese megacities and the implications for improving emission inventories, Atmos. Environ., 43, 3918-3924, https://doi.org/10.1016/j.atmosenv.2009.04.062, 2009. 